\title{
RECONFIGURING THE SUMMARY JURY TRIAL
}

\author{
Thomas B. METZLOFF*
}

\section{INTRODUCTION}

The widespread interest in alternative dispute resolution (ADR) has resulted in a prohiferation of techniques and strategies, each promising important contributions to the fair and efficient resolution of disputes. ${ }^{1}$ Judicial policy makers are understandably interested in reaping the benefits offered by particularly effective ADR methods. Faced with limited resources to develop and implement ADR programs, however, policy makers must choose among competing approaches-a choice often inade difficult by limited information on how particular processes have performed.

The difficulties in analyzing ADR initiatives are particularly acute with the summary jury trial (SJT), an ADR method developed in the federal courts in the early 1980s. As described in the hiterature, the SJT is targeted at cases that cannot be resolved by traditional settlement processes. ${ }^{2}$ In an SJT, an abbreviated version of the dispute is submitted to a jury, which renders an advisory verdict intended to assist the litigants in reevaluating the possibility of settlement. Judging by some accounts, the SJT has enjoyed a fair measure of success in soine federal courts, and is regularly touted as a useful addition to state court ADR

* Professor of Law, Duke University School of Law. Research Fellow, Private Adjudication Center, Inc.

The research described in this Article was supported by a grant from the Robert Wood Johnson Foundation (Grant No. 12414) to study the use of alternative dispute resolution mechanisms in medical malpractice cases, as well as a grant from the North Carolina State Bar Plan for Interest on Lawyers' Trust Accounts (IOLTA) (Grant No. 90-2-18) to study the use of summary jury trials in North Carolina. The views expressed here are those of the author. Don Willett, Duke University School of Law Class of 1992, performed valuable research assistance in the preparation of this Article.

1. For a general review of $A D R$ techniques and discussion of issues relating to their development and use, see STEPHEN B. GoldBerg ET AI., DispUte Resolution (1985); Jethro K. Lieberman \& James F. Henry, Lessons from the Alternative Dispute Resolution Movement, $53 \mathrm{U}$. CHI. L. REv: 424 (1986); see also Maurice Rosenberg, Resolving Disputes Differently: Adieu to Adversary Justice?, 21 CREIGHTON L. REv. 801, 809 (1988) ("[T] he ideal system will require deploying a whole battery of dispute-resolving mechanisms, variously directed, variously driven and variously employed.").

2. See infra text accompanying notes 34-35. 
offerings. Recently, however, critics have asserted that the process is unreliable, conceptually unsound, and arguably illegal. Although these opposing accounts inight be reconciled by well-designed studies, apparent difficulties with conducting empirical research have resulted in a notable lack of evidence on the SJT's performance.

Although generally critical of the SJT as presently conceived, this Article is not intended as another denouncement of the process. To the contrary, its central contention is that this ADR method, once freed from artificial limitations placed upon it by its earliest users, can fulfill a distinct and useful role. Part I describes the philosophy and history of the SJT, focusing particularly on how the process is intended to foster settleinents and evidence concerning its use. Part II presents a detailed account of an effort by the North Carolina state court system to use SJTs. The description of this experimental program-one of the first state court attempts to harness the SJT's potential-reveals several unexpected difficulties in realizing its supposed benefits. The most notable finding was the almost total lack of interest among hitigants in employing the process in its traditional non-binding format. Although this low level of use inay refiect design flaws in the program or its impleinentation, it is also possible that few state court cases are well suited to the process or that the non-binding approacl is inherently defective. The suitability of state court cases is further explored in Part III, where a separate examination of the pool of trial cases in medical inalpractice disputes (an important part of most state courts' trial dockets) reveals that the SJT offers only marginal potential benefits.

Part IV revisits the theory of the SJT. A noteworthy aspect of the Nortl Carolina program was the interest among litigants in using (and a corresponding willingness by the court systein to perimit such use of) the summary jury as a binding ADR metlod. Part IV argues that further attention to the summary jury trial's potential as a binding process is warranted. Although at first blusli binding SJTs may seem inconsistent with its purpose and structure, a binding approacl overcomes most of the current criticisms of the SJT. Accordingly, it offers a promising ADR opportunity for resolving certain high-stakes disputes.

\section{The Classic Summary Jury Trial: History, THEORY, AND PRACTICE}

In whiat this Article will refer to as the "classic" SJT, the opposing attorneys briefly present their respective cases before a jury that renders a 
non-binding verdict. ${ }^{3}$ To minimize the parties' expense and the use of court time, the SJT is greatly abbreviated in comparison to a traditional trial; common descriptions of the process suggest that a typical SJTtargeted at cases that usually require a week or more to try-could be completed in one day or less. ${ }^{4}$ This economy is achieved by using various procedural shortcuts, such as restricting questioning during jury selection, minimizing evidentiary objections, omitting marginal evidence, and curtailing jury instructions. The most important elennent-usually considered the SJT's sine qua non-is the use of attorney summaries of evidence in hieu of live testimony. 5 In this way, the classic SJT imitates, but hardly rephicates, a traditional jury trial. ${ }^{6}$

3. A useful summary of a paradigm non-binding SJT is provided in the following quotation from the first article describing the process:

The summary jury trial is a half-day proceeding in which attorneys for opposing parties are each given one hour to summarize their cases before a six-member jury. Basically, imtroduction of evidence is limited, and witnesses are excluded from the proceeding. After the evidence has been presented and the judge provides a short explanation of the law, the jury retires and either presents a consensus verdict or, if no consensus can be reached, reveals anonymous individual juror views. The jury's verdict is purely advisory, unless the parties agrce to be bound by the verdict. The main purpose of the procedure is to provide parties with an insight into the way a trial jury would view the case without the expenditure of time and money required for a full trial.

Thomas D. Lambros \& Thomas H. Shunk, The Summary Jury Trial, 29 Clev. ST. L. REv. 43, 43 (1980); see also Hugh W. Brenneman \& Edward Wesoloski, Blueprint for a Summary Jury Trial, 65 Mich. B.J. 888 (1980); Thomas D. Lambros, The Summary Jury Trial and Other Alternative Methods of Dispute Resolution, 103 F.R.D. 461, 470-71 (1984).

4. In practice, there would appear to be no established or preferred length; SJTs have been as short as a few hours or as long as a week or more. See McKay v. Ashland Oil, Inc., 120 F.R.D. 43 (E.D. Ky. 1988) (involving a five-day SJT). See generally James J. Alfini, Summary Jury Trials in State and Federal Courts: A Comparative Analysis of the Perceptions of Participating Lawyers, 4 OHo ST. J. ON Disp. RESOL. 213, 229 (1989) (table 5) (noting that 86\% of Florida state court SJTs were conducted in a half day, as compared to only eight percent of Florida federal court SJTs).

5. See, e.g., S. Arthur Spiegel, Summary Jury Trials, 54 U. CIN. L. REv. 829, 829 (1986); see also Richard L. Marcus, Completing Equity's Conquest? Reflections on the Future of Trial Under the Federal Rules of Civil Procedure, 50 U. PITT. L. REv. 725, 751 (1989) (noting that "allowing live testimony seems to be beyond the scope of the proceeding"). For descriptions of the types of evidence allowed and related restrictions, see Thomas D. Lambros, Summary Jury Trials, LITIG., Fall 1986 , at 52, 53. In fact, different judges have employed a variety of formats, including differing approaches to limiting evidence. See D. Marie Provine, SettLEMENT Strategies for FedERAL DisTRICT JuDGES 68-76 (1986) (discussing the flexibility of SJT formats); Gerald L. Maatman, Jr., The Future of Summary Jury Trials in Federal Courts: Strandell v. Jackson County, $21 \mathrm{~J}$. MARShall L. Rev. 455, 46465 (1988) (same).

6. For an interesting analysis of the qualitative differences between an SJT and a conventional trial, concluding that the SJT should be used cautiously pending further testing to understand the impact of the differences between it and a traditional trial, see Joan $\mathbf{K}$. Archer Rowland, Comment, Communication and Psychology Variables: Reasons to Reject the Summary Jury Trial as an Alternate Dispute Resolution Technique, 39 KAN. L. REV. 1071 (1991). 


\section{A. The History of the Classic Summary Jury Trial}

Unlike other ADR methods whose roots extend back decades if not centuries, the SJT is of recent origin. First used in 1980, the SJT is the innovation of Judge Thomas Lambros, a federal district court judge in Ohio. ${ }^{7}$ Rather than relying on higants to volunteer, Judge Lambros, as well as many other federal judges interested in testing the process, typically compelled participation based upon the assumptions that judges were best able to identify suitable disputes and that the same dynamics that prevented litigants froin settling would likely interfere with their agreeing to the use of this or any other ADR inethod. ${ }^{8}$

The SJT quickly came to occupy an enviable miche among ADR adherents. Enhanced by active judicial support (which at times approached evangehical fervor), the SJT was almost immediately accepted

7. See Thomas D. Lambros, The Federal Rules of Civil Procedure: A New Adversarial Model for a New Era, 50 U. PrTr. L. REv. 789, 798-804 (1989). If one is willing to stretch the conception of a summary trial, a predecessor of sorts was considered in Capital Traction Co. v. Hof, 174 U.S. 1 (1899). In Hof, the Supreme Court approved a District of Columbia rule that required litigants to try their case first to a jury presided over by a lay court official, but required that the hitigants be afforded the right to a trial de novo before a jury presided over by a "regular" judge. See id. at 4143.

8. See, e.g., William E. Craco, Note, Compelling Alternatives: The Authority of Federal Judges to Order Summary Jury Trial Participation, 57 FoRDHAM L. REv. 483, 499 (1988) (suggesting that the "major obstacle to widespread use of SJTs are the suspicions of unwary practitioners, unaware of the benefits of the procedure," thus justifying mandatory judicial referrals). Not all federal judges mandate the procedure; several judges merely suggest its use. See, e.g. , Associated Pa. Constructors v. Jannetta, 738 F. Supp. 891, 895 (M.D. Pa. 1990) (providing that the parties shall notify the court if interested in using an SJT according to the court's suggested format); Hall v. Ashland Oil Co., 625 F. Supp. 1515, 1523 (D. Conn. 1986) (requesting parties to consider the use of an SJT because of the "many factual uncertainties involved in this case ... and the apparent absence of independent progress towards settlement").

SJT proponents have suggested that authority for mandating its use can be found primarily in Rule 16 of the Federal Rules of Civil Procedure, which deals with the court's power to conduct pretrial conferences, as well as in the Court's inherent powers to control its docket. See Lambros \& Shunk, supra note 3, at 51-52; Glenn Newman, Note, The Summary Jury Trial as a Method of Dispute Resolution in the Federal Courts, 1990 U. ILL. L. Rev. 177, 193-95. Courts and commentators have also relied on (1) local rules authorizing SJTs pronulgated under Federal Rule of Civil Procedure 83, see McKay v. Ashland Oil, Inc., 120 F.R.D. 43, $44-46$ (E.D. Ky. 1988), and (2) Federal Rule of Civil Procedure 39(c), which permits the use of advisory juries as additional sources of autliority. See Note, Practice and Potential of the Advisory Jury, 100 HARV. L. REv. 1363, 1368 (1987) (describing the SJT as an "innovative use of the advisory jury" procedure). For a useful discussion of the asserted bases for judicial power to mandate the SJT, see Clarles F. Webber, Note, Mandatory Summary Jury Trial: Playing by the Rules?, 56 U. CHI. L. REV. 1495 (1989). See generally Dwight Golann, Making Alternative Dispute Resolution Mandatory: The Constitutional Issues, 68 OR. L. REv. 487 (1989) (analyzing various constitutional issues relating to the use of ADR, including the SJT). For commentary dealing with the issue of the advisability of mandatory SJT referrals, see infra note 28. 
within the lexicon of the ADR movement and its use became commonplace in a few federal district courts. ${ }^{9}$ Its popularity is generally attributed to its unique rehance on lay jurors, ${ }^{10}$ although it is also probably the case that judges and litigants are more comfortable with its format because it relies more on traditional adversarial presentation than do other ADR methods (such as mediation) that seek to substitute a different dispute resolution orientation. ${ }^{11}$ In addition, the SJT's quick rise through the ranks of accepted $\mathrm{ADR}$ methods was also attributable to the fact that it is one of the few alternative procedures specifically designed for complex cases. 12

9. See Provine, supra note 5, at 68 (noting that as of inid-1980s, inore than 25 federal judges had used the process); Lambros, supra note 7, at 802 (estimating that a total of 1000 SJTs have been conducted in federal and state courts).

10. As noted in a recent judicial decision, the SJT "is the only dispute resolution technique which uses the input of a jury of laymen as fact finders. It is this facet of the SJT which permits the parties, not the attorneys, to believe that their story has been told, and a decision reached by an objective body." Federal Reserve Bank v. Carey-Canada, Inc., 123 F.R.D. 603, 605 (D. Minn. 1988). This same feature has been regularly noted by coinmentators as a inajor advantage of the process. See, e.g., Spiegel, supra note 5, at 834 (arguing that the SJT verdict is "more realistic and a better reflection of coininunity attitudes" than other ADR inethods such as arbitration).

11. See Rosenberg, supra note 1 (discussing ADR approaches in relation to the adversarial process and noting how inost court-annexed inetlods maintain important elements of the adversarial system); Nina J. Spiegel, Comment, The Mandatory Summary Jury Trial in Federal Court: Foundationally Flawed, 16 PEPP. L. REv. S251, S254-55 (1989) (noting that the SJT process appeals to "the emotional seuse of justice, consistent with the American justice systenn's concepts of ventilation and confrontation in a structured adversarial system"). Moreover, there are other aspects of the SJT that make it less threatening to those trial attorneys comfortable with the current adversarial system. For example, it has never been suggested that the SJT result should be adinissible at a subsequent, conventional trial, or that the court system should inpose a penalty on litigants who insist upon a traditional trial. Cf. Golann, supra note 8, at 545-46 (detailing penalty provisions and admissibility rules associated with other ADR programs).

12. See Tunothy Kratz, Comment, Alternative Dispute Resolution in Complex Litigation, 57 UMKC L. REv. 839, 840 (1989) (noting the utility of the SJT in complex cases as opposed to "[t]ypieal alternative inechanisıns such as mediation and family or neighborhood justicc centers [which] are not sophistieated enough to handle such cases, especially considering that conplex cases often necessitate sufficient discovery to achieve settleinent"). 
SJT advocates billed it as accurate, ${ }^{13}$ useful for a wide variety of case types, ${ }^{14}$ easy to implement because it required little additional administrative support, ${ }^{15}$ and cost effective for both the parties and the court. ${ }^{16}$ Indeed, its proponents went so far as to hail it as a "no risk" procedure because, even if the parties did not settle, the efforts invested in the SJT would help in preparation for the full trial. ${ }^{17}$ Spurred by glowing reports of SJT's apparent success in the federal setting, state courts expressed interest in the process in the imid-1980s. ${ }^{18}$ This initial wave of support

13. See Recent Developments, Procedure, Summary Jury Trials in the United States District Court, Western District of Oklahoma, 37 OKLA. L. REv. 214, 216 (1984) (comparing SJT verdicts in Oklahoma with subsequent trial results and finding that they were consistent).

14. See, eg., Provine, supra note 5, at 69 ("Judges are finding that summary jury trial is useful in a broad range of case types."); Brenneman \& Wesoloski, supra note 3, at 888 (noting wide use of the process because "[w]e have not detected . . . any readily discernible pattern of cases best suited for a SJT"); Lambros, supra note 7, at 799 ("My experience has shown that the summary jury trial is useful for all kinds of cases. While 1 imitially submitted non-complex matters to summary juries, I have seen the procedure work very effectively for product liability, antitrust, patent and copyright infringement, and employment cases.").

15. See Celeste F. Bremer \& W. Scott Simmer, One Day in Court: Suggestions for Implementing Summary Jury Trials in Iowa, 36 DRAKE L. REv. 297, 313 (1986-1987) (asserting that the SJT represents "one of the most promising of the alternatives available because it requires no additional training or resources to implement").

16. See, e.g., Lambros, supra note 7, at 801 (estimating that the court saved over $\$ 90,000 \mathrm{~m}$ juror fees by conducting 60 SJTs in lieu of traditional trials); Spiegel, supra note 5, at 834 (reporting that eight SJTs requiring only 17 days of trial time would have required 135 days if tried conventionally).

17. See, eg., Provine, supra note 5 , at 75 (noting that lawyers will be better prepared even if no settlement occurs); William D. Quarles et al., Summary Adjudication: Dispositive Motions AND Summary Trials 247 (1991) (quoting Judge Lambros as saying that even if no settlement occurs, "the lawyers are able to come to a stipulation with respect to various facts that would otherwise be in dispute" so that "[t]he actual trial ... is reduced by at least the amount of time taken by the summary jury trial, or more. It enhances the quality of the trial itself."). In fact, any observed impact on the conventional trial may be a function of other pre-trial managerial requirements imposed by the judge who mandated the SJT. See Negin v. City of Mentor, 601 F. Supp. 1502, 1506 (N.D. Ohio 1985) (ordering that if the SJT did not resolve dispute, the parties must prepare and exchange written summaries of testimony in part because the exercise of preparing the summaries "tends to distill out the essence of each witness's testimony").

18. Use of SJTs in state courts has been reported as early as 1983. See Alfini, supra note 4, at 215 (noting use of an SJT in 1983 in a Florida state court); see also Bixler v. J.C. Penney Co., 376 N.W.2d 209, 214 (Minn. 1985) (referencing the use of an SJT in a Minnesota state court). See generally Bremer \& Simmer, supra note 15, at 315 (suggesting that SJTs "could prove to be an invaluable tool in the extrajudicial arsenal that Iowa courts may utilize to resolve burgeoning caseloads"). At least three states have statutory provisions that expressly allow for the use of SJTs in their state court systems. See Neb. Rev. STAT. \$§ 25-1154 to -1157 (1989); Tex. Civ. Prac. \& REM. CODE ANN. § 154.026 (West Supp. 1992); VA. CODE ANN. \$§ 8.01-576.1 to -576.3 (Michie Supp. 1991). Other states have relied on local court initiatives. See infra note 51 (discussing evidence of the use of SJTs in state courts). 
perhaps crested when the Judicial Conference of the United States formally endorsed the "experimental use" of SJTs a niere four years after the process was first employed. 19

Criticisms soon surfaced, however. Beginning with an article by Judge Richard Posner that questioned both its utility and ethical propriety, ${ }^{20}$ the SJT has been subjected to a series of nicreasnigly virulent attacks that have exposed a number of weaknesses thought to be inherent in the SJT. ${ }^{21}$ Critics, for example, have detailed the difficulties a summary jury has in assessing witness credibility given its reliance on lawyers' summaries of evidence. ${ }^{22}$ Similarly, solne have questioned whether

19. See Judicial Conference of the United States, Report of the Proceedings of THE JUDICIAL CONFERENCE OF THE UNITED STATES 88 (1984) (endorsing the "experinental use of summary jury trials as a potentially effective ineans of promoting the fair and equitable settlement of potentially lengthy civil jury cases"), cited in Strandell v. Jackson County, 115 F.R.D. 333, 335 (S.D. III. 1987). The initial draft of the resolution provided:

[T] he Judicial Conference endorses the use of summary jury trials, only with the voluntary consent of the parties, as a potentially effective means of promoting the fair and equitable settlement of lengthy civil jury cases. With proper authorization by local rules, suinınary jury trials are recommended to District Courts for consideration as an optional device.

Judicial Conference of the UnITEd STATEs, Report of Judicial Conference CommitTeE ON THE OPERATION OF THE JURY SySTEM AGENDA G-13, at 4 (1984), cited in Strandell, 115 F.R.D. at 334-35 (emphasis added in Strandell). The language dealing with voluntary consentwhich was inconsistent with actual judicial practice-was dropped.

20. See Richard A. Posner, The Summany Jury Trial and Other Methods of Alternative Dispute Resolution: Some Cautionary Observations, 53 U. CHI. L. REv. 366 (1986). Posner's specific concerns about the SJT focus on three inajor points. First, he questions whether the SJT has contributed to a reduction in court backlogs in those districts in which it has been widely used. For example, Posner found that although the number of civil trials in the Northern District of Ohio (which employed the SJT regulariy) had in fact declined, this trend began prior to the time that SJTs were first employed. Id. at 379 . Second, he challenged whether the process, at least when inandated by federal courts, was authorized by the existing rules. Id. at 385 . Third, he questioned the ethics of not informing summary juries that their results would not be binding. Id. at 386-87.

21. See Shirley A. Wiegand, A New Light Bulb or the Work of the Devil? A Current Assessment of Summary Jury Trials, 69 OR. L. REV. 87 (1990):

[Because] rules of evidence in an SJT are so relaxed as to be nearly nonexistent, and because lawyers inay have only one or two hours to suminarize what in a normal trial would take several weeks or more, one must ask whether the jury verdict in the proceeding is at all valuable. ... Instead of judging the credibility of witnesses, the jury assesses the credibility of the attorneys, which might also lead to a skewed verdict.

Id. at 99; see also Rowland, supra note 6, at 1079 (suggesting that because of the differences in how information is cominumicated to the summary jury, "there is hittle guarantee that a suinınary proceeding lasting a few hours can ensure aceuracy and reliability at a level similar to a full-length trial"). For a colorful tirade against the SJT process, see John Feikens, The Civil Jury -An Endangered Species, 20 U. Mich. J.L. REF. 789, 797 (1987) (labeling the SJT a "creature of the devil" that, because of its lack of procedural protections, constitutes a form of "Russian roulette"). These criticisms have been recently fueled by a growing list of what appear to be aberrant SJT results. See infra note 43.

22. See Edward Brunet, Questioning the Quality of Alternative Dispute Resolution, 62 TuL. L. REv. 1, 40 (1987) (arguing that allowing STTs in cases presenting substantial issues of veracity such as intent or conspiracy "institutionalizes inaccuracy and harms dispute resolution quality"); Maatman, supra note 5, at 483 (asserting that the suminary jury process prevents the jury "froin being 
it is appropriate to permit unprepared attorneys to participate in an SJT where they might benefit from seemg their opponent's presentation prior to the subsequent "real" trial. ${ }^{23}$ Questions have also been raised as to whether the process generates any significant cost savings to the parties. ${ }^{24}$ As a result, critics have suggested that, contrary to its billing as a "no risk" procedure, the SJT might actually impede settlements or encourage settlements that are of low quality. ${ }^{25}$ In addition, even conceding that the process may prove effective in particular disputes, it has been suggested that other ADR methods-particularly court-ordered arbitration or more active judicial management of cases-would achieve comparable results with less cost to both hitigants and the courts. ${ }^{26}$

These criticisms have been reflected in a series of recent legal challenges directed against the SJT. For example, the Court of Appeals for the Seventh Circuit has held that federal judges do not have the authority to mandate the use of SJTs-a damning blow to the classic SJT theory, which depends im large part upon active judicial involvement im identifyimg appropriate cases and requiring participation to overcome litigant reticence. ${ }^{27}$ Commentators are sharply divided on the advisability of

able to reach an accurate and just assessment of credibility"). Eveu judges who have used the process regularly have recognized this conccrn. See Spiegel, supra note 5, at 835 . But see Bremer \& Simmer, supra note 15, at 313 (noting that the "cathartic experience of [parties having] their day in court" makes SJTs useful even in "swearing contest[s]").

23. See, eg., Provine, supra note 5, at 70 (noting reports that "the procedure does not work well when lawyers are mexperienced or unprepared"); Maatman, supra note 5, at 486 (noting that the use of SJTs "by ill-prepared counsel notivated by a desire to gain a strategical advantage at the subsequent full trial on the inerits will only reduce the rehability of the advisory verdict and destroy the procedure's perceived theoretical efficacy to promote settlement").

24. See Maatman, supra note 5, at 482 (noting that "the parties may incur costs comparable to preparation for a full trial, even in circumstances where settlement is achieved"); Sherilyn Peterson, Summary Jury Trial Strategies, LrTIG., Spring 1990, at 31, 62 (noting that "an SJT can easily double the cost of pretrial preparation without resulting in settlement"); see also Federal Reserve Bank v. Carey-Canada, Inc., 123 F.R.D. 603, 604 (D. Minn. 1988) (noting objections by counsel to judicial referral to an SJT on the grounds that it would cost approximately $\$ 50,000$ per party to prepare for and conduct the procedure).

25. See, e.g. Alfini, supra note 4, at 225 (noting that receipt of a zero verdict in a case in which defendant had made a prior offer may undercut settlement negotiations because the defendant will retract or lower any offers that may have been made prior to the SJT); Posner, supra note 20, at 387 (suggesting that a corporation that loses an SJT inay be forced to settle on potentially unfavorable terms). As a partial counter to these considerations, some judges require the summary jury to assess potential damages even if it finds for the defendant. See Spiegel, supra note 5, at 836.

26. See, e.g., United States v. Exum, 744 F. Supp. 803, 808 n.1 (N.D. Ohio 1990) ("Besides placing an added hardship on the parties, it remains unclear what the process has to offer over a traditional settlement conference between the parties and the judge."); Posner, supra note 20, at 382 (suggesting that other settlement methods should be explored because of "how lavish the suminary jury trial is with the judge's time: he spends a whole day trying to settle one case").

27. See Strandell v. Jackson County, 838 F.2d 884 (7th Cir. 1988); see also supra note 8. 
mandatory referrals. ${ }^{28}$ A more recent district court opinion went further and held that the federal courts have no authority to summon a summary jury even if requested by the parties. ${ }^{29}$ To be sure, other decisions have praised the process while upholding the courts' power to inandate its use; ${ }^{30}$ indeed, Congress has recently expressly authorized federal district courts to utilize the process as part of the development of coniprehensive case managenient plans. ${ }^{31}$

28. Compare Maatman, supra note 5 , at 486 (claiming that making the process mandatory in cases in whieh one side is not prepared "will only reduce the rehiability of the advisory verdict and destroy the procedure's perceived theoretical efficaey to promote settlement") and Daniel $\mathrm{K}$. O'Toole, Comment, The Catch-22 of Mandatory Summary Jury Trials, 1990 J. DiSP. Resol. 135, 147 (declaring that mandating SJTs is "doomed to failure due either to the discovery rules protecting information from disclosure prior to trial or practical consideration as to the adversarial position parties often occupy prior to trial") with Marcus, supra note 5 , at 750 (questioning the result in Strandell by noting that "[m] aking hitigants go through [an SJT] is qualitatively different from clubbing them into accepting a specific compromise"); Craco, supra note 8, at 499 (arguing that because "the major obstacle to widespread use of SJTs are the suspicions of unwary practitioners, unaware of the benefits of the procedure," mandating the use of SJTs will "not only improve the chances that the particnlar dispute will be resolved efficiently, but increase the number of practitioners who will feel comfortable with the procedure in the future"); Newman, supra note 8, at 199 (arguing that if Strandell prevails, "the result will be the destruction of the summary jury trial, not merely its modification") and Note, Mandatory Mediation and Summary Jury Trial: Guidelines for Ensuring Fair and Effective Processes, 103 HARV. L. REV. 1086, 1104 (1990) (recommending that legislatures authorize mandatory SJTs while providing certain safeguards to guarantee their faimess).

29. See Hume v. M \& C Mgmt., 129 F.R.D. 506, 510 (N.D. Ohio 1990); see also Charles W. Hatfield, Comment, The Summary Jury Trial: Who Will Speak for the Jurors?, 1991 J. DisP. RESOL. 151, 157-59 (criticizing Fume and noting that if it is upheld, parties would be forced to conduct SJTs privately, which raises a number of serious difficulties-such as ensuring random selection of jurors-thus likely resulting in the "deatl of the summary jury trial in federal court"); $c f$. United States v. Exum, 744 F. Supp. 803 (N.D. Ohio 1990) (holding that jurors summoned for crimimal trial must be discharged due to undue influence of having been exposed to the SJT process). Following the decision in Exum, Judge Lambros issued a general order relating to juror utilization that expressly pernitted use of jurors in summary jury proceedings. See United States v. Exum, 748 F. Supp. 512 (N.D. Ohio 1990). In response, Judge Battisti, author of Exum, perceiving an unwarranted interference with his judicial autliority, refused to conduct any jury trials until a new jury wheel was drawn. Id.

30. Those courts finding the power to mandate the use of SJTs focus on the need to overcome attoruey reluctance to utilize novel ADR methods. For example, in Federal Reserve Bank v. CareyCanada, Inc., 123 F.R.D. 603, 604 (D. Minn. 1988), the court noted:

Parties and attorneys are often and understandably reluctant to accept and participate in procedures outside the traditional norm. It is often difficult to focus the attention of counsel and litigants on settlement as an alternative means of resolving a case. The need to compel the parties to address settlement is an integral aspect of the docket management function of the court in this era of complex, protracted litigation.

For otler positive assessments of the process, see McKay v. Ashland Oil, Inc., 120 F.R.D. 43 (E.D. Ky. 1988); Arabian Am. Oil Co. v. Scarfone, 119 F.R.D. 448 (M.D. Fla. 1988).

31. See Judicial Improvements Act of 1990, 28 U.S.C.A. $\S 473(a)(6)(B)$ (West Supp. 1991). 


\section{B. The SJT and the Settlement Process}

The universally acknowledged goal of the SJT is to promote settlement. ${ }^{32}$ The process was judicially inspired by the perceived need to address the problem of court overload and delay; it promised to resolve intractable disputes that threatened to consume large amounts of scarce judicial resources. ${ }^{33}$ Explaining how SJTs actually promote settlement, however, has not been rigorously pursued. As a starting point, judicial proponents exhibit considerable faith in existing settlement processes. SJTs are not intended to mterrupt or supplant these current approaches, but are designed for cases shown to be intractable ${ }^{34}$-an attitude probably justified more by the perceived necessity of avoiding trial than any inherent confidence in the underlying equities of current settlement practices. 35 Once focused on this core of settlement-resistant disputes, the SJT's settlement enhancing powers have been explained under at least four different theories.

32. See, e.g., Alfini, supra note 4, at 234 (stating that the SJT is "not a freestanding dispute resolution device," but "is merely an adjunct to settlement negotiations between the parties"). Indeed, SJTs have been ordered closed to the public to better facilitate settlement negotiations. See Cincinnati Gas \& Elec. Co. v. General Elec. Co., 854 F.2d 900, 904 (6th Cir. 1988) (rejecting newspaper's request to observe SJT because "[a]t every turn the summary jury trial is designed to facilitate pretrial settlement of the litigation, mucl like a settlement conference"), cert. denied, 489 U.S. 1033 (1989).

33. See Bremer \& Simmer, supra note 15, at 298 ("[E]conomy of judicial time requires that some attempt be made by the court to explore the possibility of settlement with counsel and their clients" in complex cases); Newman, supra note 8, at 181 (noting that the SJT provides judges with "a weapon ... to fight backlogged dockets"); cf. Lockhart v. Patel, 115 F.R.D. 44, 47 (E.D. Ky. 1987) ("[T]he exigencies of modern dockets demand the adoption of novel and imaginative means [such as the SJT] lest the courts, mundated by a tidal wave of cases, fail in their duty to provide a just and speedy disposition of every case.").

34. See, e.g., Provine, supra note 5, at 70 ("If summary jury trial is to be cost-effective, it must be reserved for cases that are unlikely to settle on their own or with less demanding court assistance."). The SJT's focus on intractable cases implies that it is not to be used until discovery is completed and the case is ready for trial, because it is only at this point that a judge could be reasonably confident that the case would not settle on its own accord. See Thomas D. Lambros, The Judge's Role in Fostering Voluntary Settlements, 29 VILL. L. REv. 1363, 1376 (1984). But see Compressed Gas Corp. v. United States Steel Corp., 857 F.2d 346 (6th Cir. 1988) (finding that trial court's decision to permit additional discovery following SJT was not an abuse of discretion). Obviously, this perspective is from that of the courts, not necessarily that of litigants wlo might benefit if an SJT were used to resolve a dispute early in the litigation process even if it would have settled prior to trial. Perhaps in response to criticisms that awaiting the completion of discovery limits potential cost savings, Judge Lambros lias recently suggested earlier use of SJTs. See QUARLES, supra note 17 , at 246.

35. See Owen M. Fiss, Against Settlement, 93 YALE L.J. 1073 (1984) (questioning recent judicial initiatives designed to promote settlement, including the developinent of various ADR metliods); Marc Galanter, The Quality of Settlements, 1988 Mo. J. DisP. RESOL. 55 (noting the importance of addressing the qualitative nature of settlement). 
1. The Jury Preview Effect. The most often cited justification for the SJT is that the attorneys will afford the surrogate verdict substantial weight in their settlement calculus. Because of the high cost of trial and its attendant risks, most cases settle if the parties have reasonably similar views of the likely odds of prevailing and the probable damages that might be awarded. Trial often represents an unnecessary failure of negotiation in which the attorneys (who for the moment are assumed to be primarily responsible for formulating settleinent strategies) have misvalued the case. ${ }^{36}$ SJT proponents surmise that litigants can inaintain differing assessments, even in the light of accumulating evidence obtained through discovery, primarily as a result of the uncertainty associated with foretelling how a jury might decide the case.

The SJT overcomes this valuation gap by providing an important clue as to how a typical jury would respond. In theory, the verdict impacts the attorneys' bargaining positions-a proposition that at first glance seems perfectly plausible. A plaintiff's lawyer cannot as easily contend that a case is worth $\$ 1$ million when a summary jury has just awarded $\$ 100,000$; similarly, defense counsel cannot credibly insist that the defendant will prevail on liability after a summary jury finds negligence. To supplement this effect, the attorneys and parties are usually encouraged after the summary verdict has been rendered to meet with the jurors to inquire into their thought processes. This debriefing provides additional imput to assist the attorneys in predicting what a real jury might do. ${ }^{37}$ The quality of the jury's result or decisionmaking process is obviously important; the SJT will be effective under this theory only to the extent that litigants value the verdict as a fair reflection of what a "real" jury would do. ${ }^{38}$

36. For support of the proposition that many trials represent failures of negotiation, see Robert Cooter et al., Bargaining in the Shadow of the Law: A Testable Model of Strategic Behavior, $11 \mathrm{~J}$. LEGAL STUD. 225 (1982).

37. See QUARLES, supra note 17, at 236 ("During this debriefing, the parties obtain firsthand knowledge of juror attitudes and gain some sense of the time risks of litigation."); Susan Tillotson, Note, Summary Jury Trials: Should the Public Have Access?, 16 FLA. ST. U. L. REv. 1069, 1073 (1989) (noting that discussion with jurors is "unique to summary jury trials and often forms the basis for settlement negotiations"). But see Associated Pa. Constructors v. Jannetta, 738 F. Supp. 891, 895-96 (M.D. Pa. 1990) (describing SJT procedures in which follow-up with jurors was limited to "leading questions which are susceptible of a yes or no answer or a dollar figure" and that no questions "shall be asked which would require an answer disclosing the personal view of any jury meinber").

38. See Peterson, supra note 24, at 31 ("Perceived predictive force is the key: If the parties do not believe that the verdict is predictive, the use of an SJT as a settlement tool is pointless."). This point does not require that the parties accept summary verdicts as exact replications of what traditional juries might award. If the parties acknowledge that a particular SJT verdict was probably influenced by the exclusion or inclusion of certain evidence, the advisory verdict can be appropriately discounted or inflated during the course of the subsequent negotiations. 
2. Party Enlightenment/Cathartic Impact. SJTs are also believed to be effective because the clients are required to attend in the hope that viewing a balanced presentation of the evidence will incline them toward settlement. ${ }^{39}$ By hearing botli sides of the issues without the filtering of information by their attorneys, chents inay, for the first time, be forced to acknowledge the strength of opposing positions or the weaknesses of their own. ${ }^{40}$ Although this nay reflect the natural difficulties that disputants have in developing an appreciation for an opponents' position, SJT advocates also suspect that soine attorneys fail to provide adequate information to clients, and that this problein can be overcome by the SJT.

A related assertion is that the SJT will have a cathartic effect on the hitigants. By being provided a "day in court," litigants are more likely to settle, even if the summary verdict does not convince parties to rethink the merits of their position. The satisfaction of having had their concerns considered is often a sufficient spur for litigants to revisit the question of settleinent. ${ }^{41}$

3. The Scheduling Impact. Another view is that merely scheduling a case for an SJT may result in settlement. Because some attorneys do little preparation without prodding, estabhishing a firm date for trialeven a non-binding one-forces attorneys to review the inerits of the case, which might serve to change their appraisal of the likely outcome.42 On a more practical level, the ministerial acts of preparing for an SJT

39. On the necessity of parties attending the SJT, see Provine, supra note 5, at 74 (noting a consensus that "[c]hents or other persons with full authority to settle the case must be present if the process is to be effective"); Brenneman \& Wesoloski, supra note 3, at 889 ("It is essential that the principals ... have an opportunity to see and hear a presentation of their opponent's arguments as well as their own, and to personally gauge the impact of the case on the jury."). See generally G. Heileman Brewing Co. v. Joseph Oat Corp., 871 F.2d 648, 652-53 (7th Cir. 1989) (en banc) (upholding authority of district judge under Federal Rule of Civil Procedure 16 to require presence of chent representative with authority to settle at pre-trial conference).

40. See Provine, supra note 5, at 74 (noting that an SJT is "ideally designed to convince a client that the hikelihood of prevailing at trial is not as great as the chent perceives it to be" and thus serves to overcome any attorney-client communications problems).

41. See McKay v. Ashland Oil, Inc., 120 F.R.D. 43, 50 (E.D. Ky. 1988) (discussing low SJTs satisfy the litigants' "psychological need for a confrontation" and "provide a therapeutic release of this emotion"); see also Lambros, supra note 5, at 53 ("The psychological satisfaction of courtroom combat is important to many litigants.").

42. See Alfim, supra note 4, at 222 (noting that analysis of settlement rates in a mandatory SJT program "reinforces the opmion that the scheduling of a firm trial date (albeit a summary jury trial date) encourages the parties to enter into serious settlement discussions, thereby accelerating the decision to settle"); Lambros, supra note 7, at 799 (suggesting that preparation for an SJT creates tensions similar to a regular trial so that the "shadow of an approaching summary jury trial will intensify" the parties' settlement efforts); $c f$. Arabian Am. Oil Co. v. Scarfone, 119 F.R.D. 448, 449 (M.D. Fla. 1988) (noting that many attorneys are ill-prepared for trial, and that " $[t]$ he reality is that too many will not get ready until the day of a trial; a summary trial forces that day and that preparation") 
provide occasions for contact between opposing counsel and clients (sucl as during pre-SJT conferences) that might facilitate negotiations.

4. The Fear/Exhaustion Factor. A final projected inpact, one not as loudly proclamied as the others, is that SJTs foster settlement by providing litigants with an exposure to the vagaries and expense of the jury system that tends to discourage interest in further litigation. Thus, even if a summary jury result is irrational, it may function to lighliglit the inherent risk associated with juries. ${ }^{43}$ Similarly, because the SJT process admittedly entails some expense, the parties will realize that the "real" trial will be even more costly. 44 In either case, the result is to foster a greater willingness to end the dispute.

The above review of the sundry explanations offered to illuminate the SJT's settlement-enhancing powers permits several preliminary observations. First, the importance of the quality of the summary jury's decision varies considerably among the differing theories. Under the preview theory, for example, the quality of the suminary verdict is essential; the theory is premised upon the assumption that the result will serve as a valid predictor of what a "real" jury would award. For the other approaclies, the quality of the decision is less important. The party enlighteument effect-especially its rehance on the SJT's cathartic qualities-is

43. See, e.g., QUARLES, supra note 17, at 233 (noting that the SJT forces parties to observe how difficult it is to present their case, after which "they gain a greater sense of the risks of litigation and, often, demonstrate a greater willingness to settle"). The need to concoct such a theory was in part caused by the widely reported result in Stites v. Sundstrand Heat Transfer, Inc., 660 F. Supp. 1516 (W.D. Mich. 1987), a major product liability case subjected to an SJT format enploying two different jury panels. See Clifford J. Zatz, Toxic Tort Case Unlikely to Have Settled Without Summary Jury Trial, Lawyer Says, 2 ALternative Disp. Resol. REP. 145 (1988). One summary jury found for the plaintiff in the amount of $\$ 2.8$ million; the second found for the defendant. The case subsequently settled, and the judge deemed the process a success because it "demonstrated to both sides that they might win the case at a full trial on the merits, yet also risk defeat as shown by the inconsistency of the verdict in the summary jury trial." Richard D. Enslen, Summary Jury Trials Can Help Settlement in Toxic Tort Cases, 2 Alternative Disp. Resol. Rep. 46 (1988). See Kratz, supra note 12, at 847 (noting that divergent results in Stites may have served to "guarantee" settlement because "[e]ach party could leave the courtroom feeling as if it could win at trial, yet well aware of the risks' ") (quoting the defense attorney in Stites). For additional discussion of Stites, see Maatman, supra note 5, at 464-67; see also Compressed Gas Corp. v. United States Steel Corp., 857 F.2d 346, 348 (6th Cir. 1988) (following award of $\$ 200,000$ by summary jury, conventional trial resulted in a verdict for plaintiff of $\$ 1.77$ million); Muehler v. Land O'Lakes, Inc., $617 \mathrm{~F}$. Supp. 1370, 1372 (D. Minn. 1985) (noting that one summary jury awarded $\$ 2.2$ million while a second found for the defendant).

44. See Lambros, supra note 5 , at 52 (noting that the SJT is "particularly effective when the trip through the legal labyrinth begins to tax [the parties'] patience"); Spiegel, supra note 5, at 834 (positing that SJT serves to make parties aware of "the cost of a trial on the merits, including not only attorneys' fees but the time that is going to involve themselves, their executives, other employees, expert witnesses, etc."). 
a function of litigant participation in an adjudicatory experience, not of the perceived quality of the result. The scheduling effect is not directly related to the quality of the SJT result-it is expected to occur simply because the event was scheduled. Under the fear/exhaustion rationale, the quality of the verdict is largely incidental; indeed, one could suppose that the more outlandish or wild the SJT result, the more likely it would be to convince at least one of the litigants to settle at all costs.

A second preliminary observation, although understated in the descriptions, is that several of the justifications evidence an anti-attorney bent that is surprisingly at odds with the SJT's format, whicli depends heavily on attorney mvolvement to present evidence, often to the exclusion of direct party participation. ${ }^{45}$ For example, the party-eulightenment effect and the fear/exhaustion rationale are justified in part because attorneys may fail to give their clients reasonable advice or otherwise do not communicate witli them effectively. Similarly, the preview theory is partially based on the assumption that attorneys - particularly plaintiffs' attorneys - may have insevaluated the merits of the case because of incompetence, lack of preparation, mexperience, or otherwise culpable misperception. ${ }^{46}$

A third observation is that proponents do not make clear why the SJT is the preferred ADR approach for overcoming some of the identified barriers to settlement. Relative to other ADR options, the SJT occurs late in the dispute's development. The process is also elaborate and expensive. If, for example, there is a frequent need for parties to undergo a cathartic experience prior to settlement, mediation would seem preferable because it permits litigants a direct opportunity to vent frustrations and to explaim important concerns not technically relevant to the legal

45. This anti-attorney attitude is consistent with justifications proffered in support of other ADR inethods that einphasize client control and subordination of counsel's role. See Brunet, supra note 22, at 12; $c f$. LINDA R. SINGER, SETTLING DisPUtes: CONFLICT RESOLUTION IN BusinesS, FAMILIES, AND THE LEGAL SYSTEM 26 (1990) (describing the benefits of an ADR method known as the "mini-trial," which offers business executives a "quick, relatively inexpensive look at the realities of their dispute, without the filter of their lawyers' adversarial assessinent").

46. Indeed, the catalyst for the first SJT was judicial frustration with plaintiffs' attorneys who had refused settlement offers only to obtain lower awards from a jury. See Lambros \& Shunk, supra note 3 , at $45 \mathrm{n} .16$. One possible explanation for this function is that plaintiff' attorneys who operate on a contingency fee may tend to overestimate likely recoveries to discourage risk-averse clients froin rejecting low settleinent offers. See Melvin W. Reder, Contingent Fees in Litigation with Special Reference to Medical Malpractice, in THE ECONOMICS OF MEdical MALPRACTICE 211 (Siinon Rottenberg ed., 1978). 
issues raised. ${ }^{47}$ Similarly, court-ordered arbitration, an ADR intervention that occurs earher in a case's progression than the SJT (when additional cost savimgs are possible), is generally assumed to have a similar scheduling effect and, in addition, is probably less expensive to conduct and uses fewer judicial resources because the hearings are conducted by non-judges. ${ }^{48}$

Finally, the differing settlement theories informing the SJT are too simplistic, diffuse, or ambiguous to provide inuch guidance to judges exercising their discretion to identify suitable SJT candidates. For example, it is difficult to identify any case that does not come within at least

47. Mediation is typically described as a voluntary, non-binding process in which the mediator-a neutral third party without formal authority to decide the dispute-meets with the disputants to explore settlement opportunities. See Lon L. Fuller, Mediation-Its Forms and Functions, 44 S. CAL. L. REV. 305, 308 (1971). Mediation formats can vary significantly depending on the nature of the dispute, and may be better categorized as a style of dispute resolution rather than a process. See JAy Folberg \& Alison Taylor, Mediation: A Comprehensive Guide to Resolving ConFLICTS WITHOUT LITIGATION 130 (1984).

48. For a complete description of existing federal court-ordered arbitration programs, see BARBara S. Meierhoefer, Court-ANneXed Arbitration in Ten District Courts (1990). Witl respect to pre-arbitration settlements, Meierhoefer reports that between $22 \%$ and $40 \%$ of cases were terminated prior to the arbitration hearing. See id. at 48-49 \& Table 9. As with SJTs, however, it is unclear to what extent these pre-hearing dispositions might have occurred in the absence of the ADR intervention. See E. AllaN Lind, Arbitrating High-Stakes Cases: AN Evaluation of COURT-ANNEXEd ARBITRATION IN A UNITEd STATES District Court 34-36 (1990) (noting that a court-ordered arbitration program increased the percentage of claims obtaining some type of adjudicatory hearing). 
one of the settlement rationales described above. ${ }^{49}$ Not surprisingly, accounts of judicial approaches to case selection reveal a variety of practices. ${ }^{50}$

\section{Evidence on the SJT in Operation}

The conflictimg accounts of the merits of the SJT procedure make it difficult to determine what, if anything, should be done to encourage its development. Unfortunately, there is httle empirical evidence to contribute to the debate. ${ }^{51}$ Indeed, the shortage of systematic evaluationsespecially tests that randomly assigned cases to the summary jury procedure-has becoine a rallying cry of SJT critics. ${ }^{52}$ As a partial response, supporters have noted that because SJTs were never intended to be used indiscriminately, the random assignment of cases would fail to provide a fair test of its potential. ${ }^{53}$ The result is a stand-off between commentators

49. The case of Strandell v. Jackson County, 838 F.2d 884 (7th Cir. 1988), is illustrative. In Strandell, plaintiffs sued a local muricipality for an alleged wrongful arrest and act of police brutality that resulted in the death of their son. During discovery, plaintiffs listed numerous witnesses who might be called at trial, but the municipality opted not to depose them. Plaintiffs objected to the SJT on the ground that it would require plaintiffs' attorney to describe his evidence, which would be inconsistent with the work-product doctrine. In a perceptive article on the potential unfairness of the SJT, the plaintiffs' attorney argued that Strandell was an inappropriate candidate for an SJT referral. See Maatman, supra note 5, at 467-77; see also Paul Mattingly, Note, Compelled Participation in Summary Jury Trials: A Tale of Two Cases, 77 Ky. L.J. 421, 429 (1989) (suggesting that litigants such as the plaintiffs in Strandell should be permitted to argue that the district court abused its discretion in ordering a case to proceed to SJT). It could be argued, however, that the municipality's failure to conduct discovery indicated that either local officials or the defendant's attorneys were not taking the case seriously, a situation that the SJT might remedy. Sintilarly, it is possible that the plaintiff would be more amenable to settlement after being able to tell his story to the summary jury and experiencing the possible cathartic impact of the process. Cf. Bremtenan \& Wesoloski, supra note 3, at 889 (noting that ability to vent grievances makes SJT useful "where there is an allegation of false arrest or excessive force used during an arrest"); Richard D. Enslen, ADR: Another Acronym, or a Viable Alternative to the High Cost of Litigation and Crowded Court Dockets? The Debate Commences, 18 N.M. L. REv. 1, 22 (1988) (suggesting that "certain categories of cases, notably ... suits claiming police brutality ... ought to be considered for the SJT process").

50. One judge has described his selection process as follows: "[T]he best way of doing it is getting that gut reaction by looking the lawyers and the litigants in the face and making that determination as to whether or not it needs a summary jury trial." QUARLES, supra note 17, at 244 (quoting Judge Lambros). For a useful description of how particular judges approach case selection, see Bobby M. Harges, The Promise of the Mandatory Summary Jury Trial, 63 TEMP. L.Q. 799, 81113 (1990).

51. For an overview of existing evidence as to the SJT's utility in promoting settlement, see Wiegand, supra note 21, at 101-03.

52. See Posner, supra note 20, at $374-75$ (criticizing the lack of experimental SJTs using random assiguinent of cases as well as the lack of any systenratic collection of basic information on its use). See generally United States v. Exum, 744 F. Supp. 803, 808 n.1 (N.D. Ohio 1990) (observing that after "ten years, the summary jury trial exists as an 'experiment,' commenced without controls, carried on without standards, evaluated without criteria, and developing without direction").

53. The authors of the first study on the SJT recommended against the use of random assigument of cases in evaluating the process: "Given the numerous dintensions on which cases may vury, 
who may argue about the procedure's theoretical merits without hard proof of its actual effects.

Much of the evidence that is available consists of anecdotal reports by litigants or judges who have participated in SJTs at the federal level. A number of these reports have indicated that most cases subjected to an advisory SJT settle prior to a conventional trial. ${ }^{54}$ The timing of settlements appears to vary considerably with settlements reported before, during, shortly after, and well after the SJT hearing. ${ }^{55}$ Moreover, there is anecdotal evidence to establish that each of the settlement justifications discussed above in fact has been observed.56 Anecdotal evidence, however, also supports the critics' assertions. For example, serious questions

it would simply take too long to build up adequate samples to satisfy the requirements of statistical analysis" which, in turn, would "hinder ongoing refinement in summary jury trial procedures because the evaluation could not allow for changes in the procedure without jeopardizing the validity of the findings." M. DANIEL JACoubovitch \& CARL M. MOORE, SummaRY JuRY Trials IN THE NORTHERN DISTRICT OF OHIO 33 (1982). See Provine, supra note 5, at 76 (noting that the use of different SJT formats interferes with efforts to study the process because findings inay not be properly generalized to other formats); Enslen, supra note 49, at 29 (criticizing proposal to conduct random assignment of SJTs in part because the number of cases needed to ensure statistical signifcance would interfere with the courts' operations); $c f$. McKay v. Ashland Oil, Inc., 120 F.R.D. 43, 49 (E.D. Ky. 1988) ("It is true that to date we have only unscientific anecdotal evidence of the effectiveness of summary jury trials. But not everything in hfe can be scientifically verified.").

54. See Euslen, supra note 49, at 31 (reporting that during a four-year period, 36 of 46 nonbinding SJTs settled before traditional trial with six cases still pending); see also Alfini, supra note 4, at 223 (Table 2) (noting that nine percent of cases in a voluntary state court SJT program and 14\% of cases $\mathrm{m}$ a inandatory federal court program proceeded to trial).

55. This is partially a consequence of the fact that judges have adopted different approaches in conducting post-SJT settlement discussions. See ProviNE, supra note 5, at 75 (describing different judges' post-SJT settlement strategies). For example, Judge Lambros does not insist upon immediate post-SJT negotiations, beheving that fmitful discussions are more likely to occur a few weeks after the procedure once the parties have had time to interpret the outcome and after the losing lawyer's wounded ego has had time to heal. See QUARLES, supra note 17, at 242; see also Negin v. City of Mentor, 601 F. Supp. 1502, 1505 (N.D. Ohio 1985) (ordering a post-SJT conference to be held one weck after the SJT). Other judges prefer an immediate negotiation session in part to capitalize on the hitigants' presence and the focus provided by the summary trial. See, e.g. , Spiegel, supra note 5, at 831-32.

56. See, e.g., Enslen, supra note 49, at 24 (describing a case illustrating the cathartic effect in which a corporate officer who had insisted prior to the SJT that the corporation would never settle nonetheless inade an offer after prevailing at the SJT); id. at 23 (describing an SJT in which discussions with jurors indicated strong pro-plaintiff syınpathy despite the summary jury rendering a defense verdict, which served to convince the defendant to make a sizable settleinent offer). In addition, there is substantial evidence that the mere scheduling of SJTs results in settlements prior to the summary trial. See Provine, supra note 5, at 75 (suggesting that $30-40 \%$ of the cases settle before an SJT); Lambros, supra note 3, at $472-73$ (citing evidence on pre-SJT settlements showing that $44.3 \%$ of cases assigned to an SJT settled prior to the summary trial). The process by which cases are selected for an SJT appears to impact the amount of pre-SJT settlement. In a voluntary program where parties opt for an SJT, the settlement effect is mutcd as a result of the parties' joint interest in obtaining a summary verdict. See Alfini, supra note 4, at 221-22 (noting that only one of 54 scheduled SJTs settled prior to the summary trial in the voluntary state court program, as compared to an approximately $25 \%$ pre-SJT settlement rate in the mandatory federal court program). 
have been raised in individual cases about the impact of not informing jurors that their decisions would be non-binding. ${ }^{57}$ Recent SJT verdicts have raised questions about the rehability and consistency of the process. 58

The few systematic studies that have been conducted to date have focused on litigant satisfaction, the results of which are mixed. An early survey of participating attorneys indicated general satisfaction with SJTs, although researchers noted a sizable dissenting faction and were accordingly cautious in recommending its continued use. 59 More recent evidence presented by Professor Alfini suggests that attorneys view the SJT inore favorably when it is voluntarily eniployed than when inandated by the court. ${ }^{60}$ Alfini also evaluated the utility of various aspects of the SJT in fostering settleinents; his results illustrate how design features associated witli the SJT operate ni practice to impact settlenient. He found, for exaniple, that attorneys witl disputes in whicl hability was an issue particularly valued the summary jury's subjective assessinents, ${ }^{61}$ and that SJTs helped overcoine clients' "unrealistic attitudes" concerning tlie nierits of the cases. ${ }^{62}$

The existing evidence, lowever, leaves serious gaps in understanding how the SJT works to proinote settlenient. SJT proponents deeni any settleinent reached prior to a conventional trial as a "success." Even

57. Judge Enslen recounts a case that raises particular concerns on this point: A summary jury returned a defense verdict, but individual jurors later indicated they would have returned a plaintiff's verdict if they had known that the result was non-bimding. See Enslen, supra note 49, at 23.

58. See supra note 43 (describing inconsistent SJT verdicts).

59. See JACOUBOvitch \& MoORE, supra note 53, at 32 (concluding that the SJT should ouly be employed in a narrow profile of disputes). The authors surveyed attorney opimions in 37 nonbinding cases in the Northern District of Ohio in which the court ordered an SJT to be conducted. Most attorneys who participated in an SJT viewed the process as an adequate substitute for trial, although about one-third expressed the opinion that it was madequate or very poor. Id. at 12 (Table 2). Those attorneys who had lost and went on to trial were particularly negative about the procedure. See id. at 20. Significantly, most of the attorneys whose cases settled prior to SJT did not believe that assigning the case had affected the disposition, thus calling into question any umique value of the SJT under the posited "scheduling effect." Id. at 16. The authors concluded that the process was sufficiently useful to continue experimentation simce it "results in settlement in a substantial proportion of instances," and that many attorneys behieved it had created a useful unpetus favoring settlement. See id. at 31.

60. See Alfini, supra note 4, at 233-34. The negative reaction observed by Alfini with respect to the mandatory Florida federal court experience, however, may well be overstated. The cases reviewed were part of a umque-and probably ill-advised-court program that required all lengthy cases that had been pending for a certain period of tine to be submitted to an SJT without a particularized determination that the case was well suited, and without discussions with the parties. See id. at 218-29. This probably caused the referral of some cases that were inappropriate, resulting in a higher level of dissatisfaction.

61. See id. at 226.

62. See id. at 218. 
putting aside the question whether the legal system's interest in proinoting settlement is appropriate, ${ }^{63}$ it is illogical to assume a causal relationship between an SJT and a settlement simply because the dispute settles; a summary verdict may have played only a minor role in comparison to other factors that develop as a case is prepared for conventional trial. Nor can much support be gleaned from reports indicating that most attorneys or parties found the SJT "helpful" in subsequent negotiations without a more specific understanding of how the process or verdict contributed to the subsequent negotiations. The failure to confront key issues such as the reliability of SJT verdicts, the quality of summary juries' deliberations im light of the abbreviated evidence presented, ${ }^{64}$ the actual use by hitigants of advisory results, the costs of preparing for and conducting SJTs, and the dynamics of the post-SJT settlement process represent serious shortcomings im our understanding of its supposed strengths.

Against this shadowy background of incomplete information, this Article presents evidence derived from two different studies. The first study, discussed in Part II, provides a comprehensive review of an experimental program to promote the use of SJTs in the North Carolina state courts. This detailed overview-the first coinprehensive depiction of the use of SJTs im a state court settimg-provides a basis for addressing several important policy issues relating to the SJT, mcluding: (1) evaluating its potential as a voluntary process; (2) assessing its utility in the state court setting; and (3) exploring design modifications to maximize its potential benefits. To be sure, the study is itself limited; the voluntary nature of the North Carolina prograin did not generate a sufficient nuinber of SJTs to provide clear insights imto some of the more vexing questions about how the process functions. The second study, discussed in Part III, approaches the analysis from a wholly different perspective by analyzing a particular type of hitigation-medical malpractice cases. ${ }^{65}$ This study attempts to determine what role SJTs umght potentially play in

63. See Fiss, supra note 35; Galanter, supra note 35.

64. Jacoubovitch \& Moore surveyed juror reaction to the process, and noted a wide variation in juror opinion as to whether the summary presentations affected the results. See JACouBovitch \& MOORE, supra note 53, at 22 (noting juror comments such as "[t]00 much seemed left unsaid and not enough facts nade absolutely clear" during SJT process). Examining the suninary jury's deliberative process would seem particularly amenable to study. $C f$. Rowland, supra note 6, at 1088-101 (suggesting several areas in which the SJT format might negatively impact juror's cognitive and deliberative function and urging that research was needed to assess how jurors process the information presented during SJTs). Because SJTs are short, it is possible for researchers to observe the SJT, as well as the jury dehberations and any post-SJT discussions with jurors. Concerns of interference with the jury's function are mitigated by the SJT's non-bimding nature. As an exainple of the benefits of a focused examination of a jury's deliberative process, sec MOLly SELVIN \& LARRY PICUS, THE Debate OVer JuRy Performance: ObServations from a Recent Asbestos Case (1987).

65. See infra notes $126-59$ and accompanying text. 
dealing with the acknowledged hitigation problems in that context. Drawing upon a rich study of all malpractice cases filed over a three-year period im North Carolina, this analysis permits an assessment of the maximum potential utility of the SJT process and also reveals the risks involved in grantimg courts the power to mandate the use of SJTs.

\section{The Summary Jury Trial In the North Carolina State COURT SYSTEM}

\section{A. Program Design Features}

North Carolina became one of the first states to establish a formal SJT program when in June, 1987, the state Supreme Court authorized the use of the SJT in three of the state's thirty-four judicial districts. ${ }^{66} \mathrm{It}$ was hoped that the SJT program could capitalize on the perceived success im implementing court-ordered arbitration programs im both the state and federal courts in North Carolina. ${ }^{67}$ Few North Carolina attorneys, however, had any direct experience with SJTs; when the state program commenced in 1987, only a few SJTs had been conducted im North Carolina's federal courts. ${ }^{68}$ Perhaps as a result of the lack of experience, judges were not authorized to mandate the use of summary juries. ${ }^{69}$

The North Carolina Supreme Court selected urban districts for the pilot program, assuming that their dockets would include more complex

66. Support for the program was provided by the North Carolina Bar Associatiou's Dispute Resolution Committee. See North Carolina Bar Promotes Summary Jury Trials in Ongoing ADR Effort, 1 Alternative Disp. Resol. Rep. 181 (1987). The Committee also organized a series of educational programs for local bar associations and developed a manual that provided an overview of the process as well as sample judicial orders for instituting the procedure. See NorTH CARoLINA

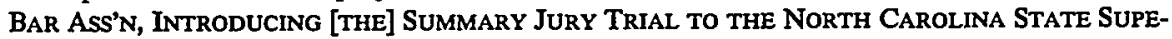
RIOR COURT (1987) [hereinafter INTRODUCING SJT].

67. For an overview of the history of the state court-ordered arbitration program, see NORTH

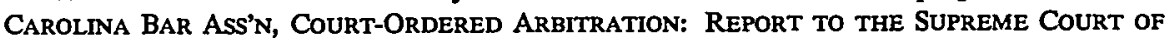
NoRTH CAROLINA (1989) [hereinafter COURT-ORDERed ARBITRATIOn]; see also Stevens H. Clarke et al., Court-Ordered Arbitration in North Carolina: Case Outcomes and Litigant Satisfaction, 14 Just. SYs. J. 154 (1991).

68. Although there is no official listing of SJTs conducted in the North Carolina federal courts, informal reports suggest that only two had been held as of June 1987.

69. It is not clear why the program's architects elected to rely on voluntary referrals in light of the SJT's mandatory nature in the federal courts. The manual prepared by the North Carolina Bar Association stated simply:

It is proposed that summary jury trials in North Carolina be initially instituted through a voluntary procedure where the judge administering tlie program in a particular district selects cases which for a variety of reasons he or she believes would be benefitted by the use of a summary jury trial, after which the parties involved consent before the procedure is actually used.

INTRODUCING SJT, supra note 66 , at 5-6. 
disputes better suited to the process. ${ }^{70}$ Neither the court nor the state's Administrative Office of the Courts established any formal procedures or guidelines to help identify appropriate SJT candidates. Instead, a judge in each district was designated to generate interest among local attorneys, identify suitable cases, and encourage the parties to agree to its use. ${ }^{71}$ Not surprisingly, implementation varied among the districts, depending upon the individual predilections of the court staffs, particularly the local trial court admimistrator (TCA), ${ }^{72}$ who was often tasked with overseeing implementation. After the program operated for several years, the state bar's Dispute Resolution Committee requested that the Private Adjudication Center, Inc., a non-profit affihate of the Duke University School of Law, review the program and make recommendations for miprovements. ${ }^{73}$

\section{B. The North Carolina Program in Operation}

1. Overview of SJT Use. During the approximately four years covered by the study, SJTs were conducted in seventeen cases. Table 1

70. The selected districts, which included the two districts with the largest caseloads in the state, were Mecklenburg County (Charlotte), Wake County (Raleigh), and Buncombe County (Asheville).

71. See INTRODUCING SJT, supra note 66, at 11 (stating that each judge "will have his or her own preferred way for determining whether a case is suitable for use of the summary jury trial procedure, and for contacting the attorneys to determine their willingness to try this technique"). It was anticipated that the first cases to go through the process would spur additional "referrals" as word spread about the procedure. See id. at 12 ("[T]rends in other jurisdictions indicate that if a few cases can be successfully resolved through means of summary jury trials, other attorneys in those jurisdictions will show increased interest in utilizing the procedure, and successful development of the summary jury trial process builds upon the prior successes.").

72. A TCA is a judicial employee charged with managing civil dockets, improving jury utilization, and performing such other duties as may be assigned by the senior resident superior court judge of the district. N.C. GEN. STAT. § 7A-356 (1990). In each district, the TCA was delegated certain duties to promote the SJT and to handle certain administrative tasks if the parties agreed to its use.

73. The Center was asked to perform the study in part because of its direct involvement in assisting litigants in conducting summary jury proceedings under the auspices of the state prograin. Possible disadvantages of its involvement were any preconceptions or biases that may have forned with respect to the proper or best use of SJTs. The Center's research culminated in a report on the North Carolina program, which included detailed histories of each of the SJT cases conducted pursuant to the program. See Thomas B. Metzloff et al., Summary Juries in the North CaroLiNA STATE COURT SYSTEM (1991). 
reveals that ten of the seventeen cases concerned claims arising froun automobile accidents. ${ }^{74}$ Eleven related to determining damages, four centered on hability, and two focused on the plaintiff's alleged contributory negligence. ${ }^{75}$

74. This is not surprising given that automobile accidents typically constitute a major proportion of state court dockets. See JAMES S. Kakalik \& Nicholas M. PACE, CosTs and CompenSaIION PAID IN TORT LiTIGATION 14 (1986) (Table 2.4) (estimating that 55\% of state court tort filings were automobile cases).

75. Not surprisingly, there was no consensus as to when the SJT process was best used. Most attorneys tended to recommend it for cases of the same type in which they used it. Thus, several attorneys who had used the process to determine damages stated that it was appropriate only in such cases. See METzLofF, supra note 73, at 38 (quoting an attorney as saying that the "most well suited cases are those where liability is absolute and it's just a question of how much"). This observation was strongly contested, however, by those attorneys who used the process to determine liability. See $i d$. (quoting an attorney as saying that "I'm convinced that the summary jury trial is great with 'all or nothing' cases with a contested liability issue"). 


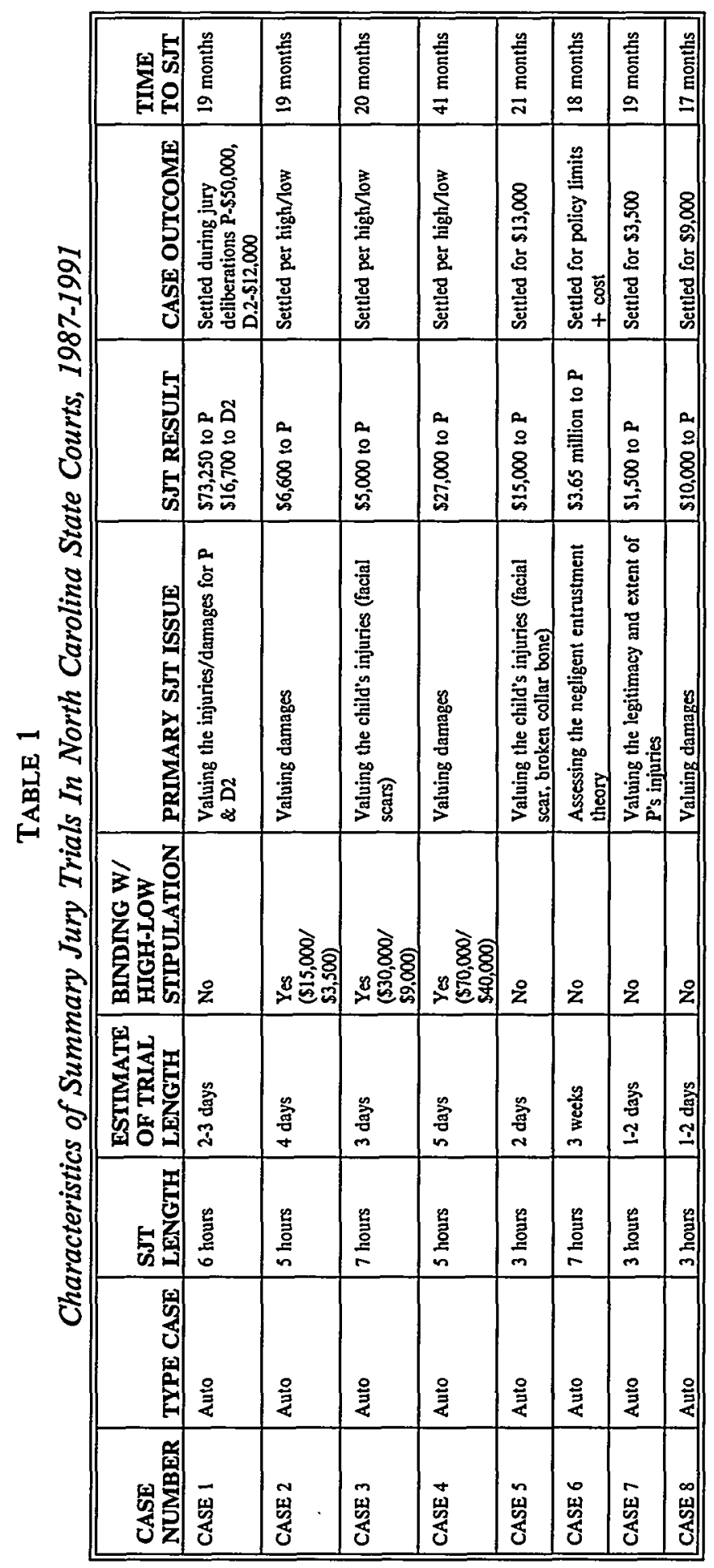




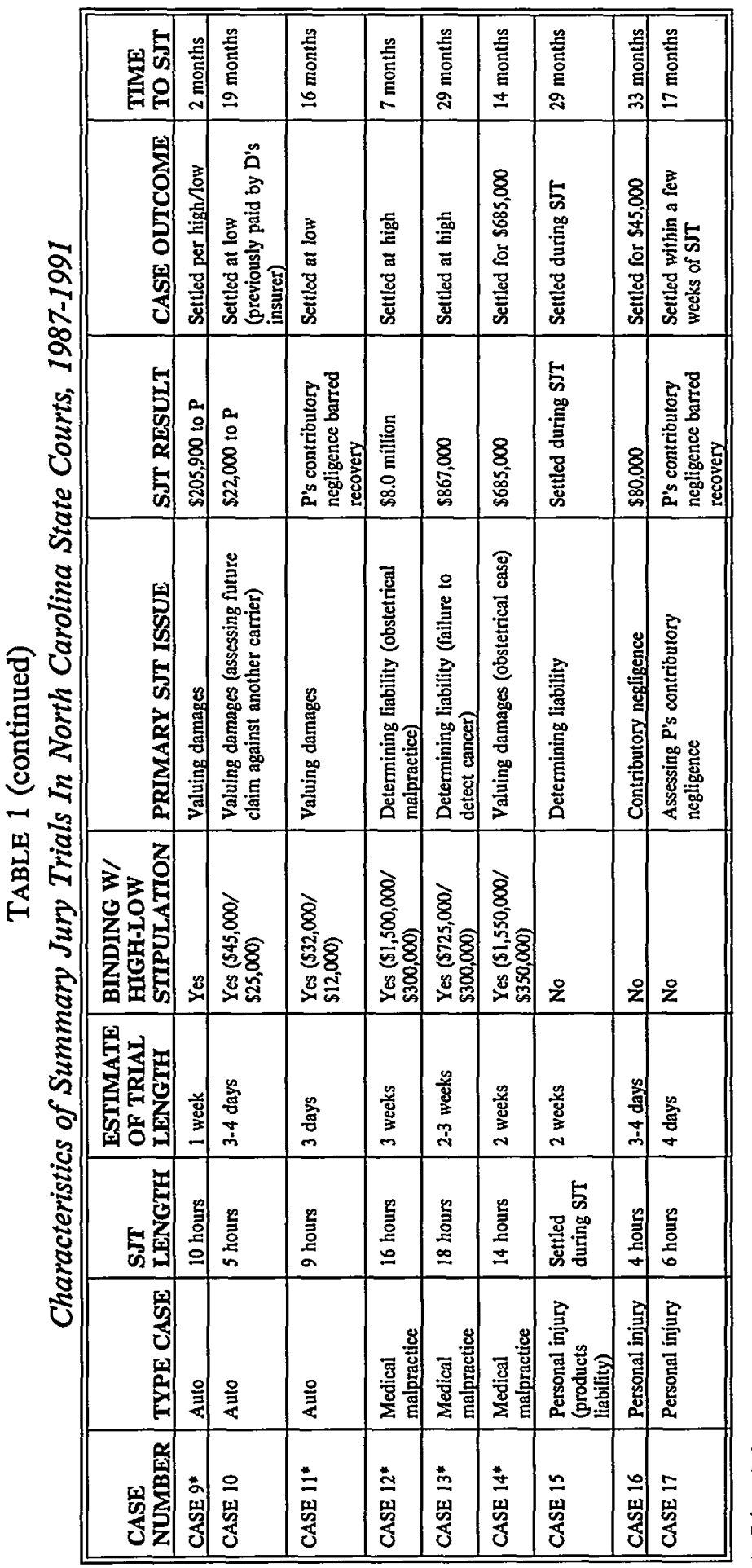


An important observation, only partially revealed through Table 1, is the variety of SJT formats employed by the litigants. ${ }^{76}$ Perhaps owing to the program's voluntary nature, litigants exercised substantial influence in designing the SJT's procedures. For example, several different metliods of jury selection were einployed, ranging from the traditional process used to select a twelve-person jury to abbreviated methods involving pre-trial screening of potential jurors and limited use of peremptory strikes to select snialler juries. ${ }^{77}$ Different approaches were also einployed with respect to the types of evidence permitted. Approxinuately forty percent of the cases (seven of seventeen cases) permitted live or videotaped testimony of key witnesses. ${ }^{78}$

Table 1 also illustrates the surprising interest among participants in converting the SJT into a binding process. The majority (nine of seventeen cases) were binding based upon prior agreenients by counsel to use the SJT format to determine tlie precise anıount of a settlenient within pre-establislied "higl//low" parameters. Indeed, soine attorneys agreed to the use of a binding SJT early in the litigation, well before the completion of potentially expensive discovery. The binding SJTs included four

76. Indeed, the variations were so substantial as to suggest the need for some clearer definition of what constitutes an SJT. For example, in one case, the local court officials characterized a proceeding as an SJT even though it lacked most attributes commonly associated with the process. See id. at 34-35 n.88 (describing Powell v. Smith, No. 89-CVS-5420 (N.C. Super. Ct. June 8, 1989 (filing date)) (Wake County)). In that case, the defendants who were founders of a church developed a plan by which church members would tum over all their income to the church in exchange for the church paying their living expenses. Plaintiffs, former church members who had participated in the scheme, alleged that the bulk of the funds collected had been expended by the defendants for their personal use. At trial, presentation of the evidence proceeded slowly, and the judge encouraged the parties to revisit the possibility of settlement. After five days of trial, the parties entered into a high/ low agreement, and also agreed to summarize some of the remaining evidence, which accelerated thc completion of the trial by a few days. Under a "high/low" agreement, the parties establish settlement parameters setting a minimum amount that the plaintiff will receive regardless of the outcome (the low), and a maximum amount that is the most that the plaintiff will receive even if the jury awards a greater amount (the high). The participants dubbed the revised procedure a "summary jury trial." The label is dubious; high/low agrecments during trial are not uncommon and do not serve to distinguish a regular trial from the more extreme modifications inherent in the summary jury concept.

77. Compare id. at 26-27 (describing Morrison v. Rozier, No. 89-CVS-609 (N.C. Super. Ct. July 23, 1990 (SJT date)) (Robeson County), in which the parties insisted upon use of the traditional jury selection process to select a 12 person jury) with id. at 23-24 (describing Fuller v. Wellman, No. 87-CVS-2787 (N.C. Super. Ct. Feb. 21, 1990) (Durham County), in which the parties agreed to pretrial screening of prospective jurors and restricted questioning to yield an eight-person jury).

78. Id. at 35. Interestingly, a number of attorneys indicated that they never explored the idea of using live testimony because it seemed inconsistent with the explanatory materials that they had reviewed. In retrospect, several expressed the belief that the process would have been fairer if some live testimony had been permitted. See id. at 43 . 
disputes with high stakes in which the amount in controversy exceeded $\$ 200,000.79$

2. Understanding Litigant Interest in the SJT. Examining why litigants opted to use an SJT provides some insiglits into how a voluntary SJT program operates in comparison to a inandatory program. As an initial observation, it is clear that the expected metlood of selection-in which judges would identify appropriate candidates and then seek voluntary referral-did not operate as planned. To the contrary, in the majority of cases the litigants themselves initiated the idea of using the SJT without direct input from the court system. ${ }^{80}$

In surveying the litigants' explanations as to why they agreed to the process, it is apparent that their strategic goals were often unrelated to the supposed virtues of the SJT as a settlement process. Several attorneys explained that their imterest was a function of their client's inability to present effectively their own testimony. For example, two disputes involved young children wliose parents did not want them to testify in court; the SJT provided a way to resolve the claim without their testifying. ${ }^{81}$ In other cases, the parties were eitlier unappealing, marticulate, or the attorney feared that the jury would be biased against them. ${ }^{82}$ In another case, the SJT was selected for its convenience in offering a firm trial date: The hitigants had been forced to postpone several potential trials owing to busy travel schedules. ${ }^{83}$ Interest in the SJT was also clearly a function of the participating attorney's familiarity with the process; discussions about the use of SJTs were often initiated by lawyers who were

79. These high stakes cases should be contrasted with the smaller stakes typically litigated under the Florida state court program as described by Alfini. See Alfini, supra note 4, at 225 n.20 (noting average award of $\$ 43,767$, with highest award of $\$ 150,000$ ).

80. Five binding SJTs were tried outside the three designated experimental districts and were initiated without any involvement of local court officials. See METZLOFF, supra note 73, at 19-30. In the remaining cases, an attorney typically initiated the idea, although indirect judicial involvement, such as judicially sponsored educational programs, may have contributed to the litigants' decisions.

81. See id. at 31-32 (describing Robinson v. Best, No. 86-CVS-8003 (N.C. Super. Ct. May 16, 1988) (Wake County)); id. at 14-15 (describing Proctor v. Barfield, No. 88-CVS-2925 (N.C. Super. Ct. Nov. 30, 1989) (Mecklenburg County)).

82. See id. at 18-19 (describing case in which attorney preferred SJT because plaintiff was inarticulate); id. at 30-31 (describing case in which the attorney suggested the use of an SJT because the defendant was Vietnamese and did not speak English well); $c f$. Rowland, supra note 6, at 1089 (noting the differences in communication theory between permitting an attorney to present the case who is "versed in the tactics and strategies of persuasive communication" and presenting the case through lay witnesses).

83. See MetZloff, supra note 73, at 32-33 (describing Levy v. Stevenson, No. 85-CVS-4646 (N.C. Super. Ct. Jan. 4, 1989) (Wake County)). 
familiar with it as a result of service on the state bar's Dispute Resolution Committee. ${ }^{84}$

\section{Perspectives on Procedural Efficiency: Trial Length and Settle-} ment. The SJT proved to be an efficient procedure in coinparison to a conventional trial; using estimates provided by counsel, SJT trial lengths were on average approximately seventy-five percent shorter than traditional trials. ${ }^{85}$ In addition, all cases using summary juries under the auspices of the North Carolina program were resolved without resort to a conventional trial. This result is not totally surprising because, as noted above, in the majority of cases the parties had agreed that the SJT result would be binding according to a pre-determined "high/low" agreement.

Examining only the non-binding SJTs provides evidence of the SJT's settlement effect. There was no clear pattern with respect to the tiuning of settlement: Two cases settled prior to the receipt of the summary verdict; four settled within a few weeks of the proceeding; and two others settled as the parties prepared for a conventional trial several inonths after receiving the summary verdict. ${ }^{86}$ Similarly, the dynamics of the post-SJT settleinent process revealed the varied roles played by the SJT verdict. All but one of the non-binding SJTs were minor cases that involved sinall potential damages. As a result, it is understandable that the litigants were reluctant to pursue further litigation. The single exception was a case in which the plaintiff suffered serious permanent injuries after being struck by a drunk truck driver einployed by the defendant coinpany. Following a one-day SJT, the jury awarded $\$ 3.65$ milhion in dainages to the plaintiff, an anount in excess of the defendant's insurance

84. See, e.g., id. at 9-10 (describing Owenby v. Beverly-Grant, Inc., No. 84-CVS-2886 (N.C. Super. Ct. July 13, 1987) (Buncombe County)); id. at 12-14 (discussing Caton v. E.L. Scott Roofing, Inc., No. 86-CVS-10374 (N.C. Super. Ct. May 17, 1988) (Wake County)).

85. Total SJT trial time in the 16 SJTs that were tried to summary verdict was approximately 120 hours. Assuming six hours of trial time per day of trial, these cases were resolved in approximately 20 trial days. See supra Table 1. The attorneys estimated that it would have taken approximately 90 days to try these same cases in a conventional format. Id. Accordingly, the SJT procedures shortened trial lengths on average by approximately $75 \%$, a finding consistent with other reports. See Spiegel, supra note 5, at 834 (estimating eight SJTs requiring 17 days of trial would have required 135 days if tried conventionally, representing an $87 \%$ reduction in trial length). Trial savings, however, varied substantially depending upon the estimated length of trial. Because several cases involved disputes in which the estimate of a traditional trial was only a few days, reductions were more modest.

86. Only limited evidence of a "scheduling effect" was observed. In one major dispute in which the conventional trial was estimated to last two months, settlement was reached the day before the SJT. See METzLOFF, supra note 73, at $35 \mathrm{n} .89$ (describing settlement in Wake Anesthesiology v. Blue Cross, No. 86-CVS-4025 (N.C. Super. Ct. May 29, 1986 (filing date)) (Wake County)). The low level of pre-SJT settlements under a voluntary program is consistent with the aceount of Florida's experience. See supra note 56. 
coverage. Although defense counsel viewed the process as helpful in providing the chent with an estimate of the risk, a different interpretation is that the advisory verdict placed undue pressure on the defendant to settle because the result exceeded the insurance coverage. ${ }^{87}$

In another non-binding SJT, the process played a possibly counterproductive role because, according to one of the attorneys, but for the SJT, the parties would have settled earher. ${ }^{88}$ In another case that settled on the eve of the conventional trial, although the SJT verdict was generally deemed useful, the relationship between the summary verdict and the settlement was obscure, in part because of the lapse of time, and in part because the ultimate settleinent was nuch lower than the summary verdict. ${ }^{89}$

On a inore positive note, a few cases illustrated the ways in which an SJT can contribute to the resolution of a dispute. For exainple, in one product hability suit both attorneys attributed an early settlement to the fact that the SJT process forced the defendant inanufacturer to focus on the dispute and the potential risks involved. ${ }^{90}$ In other cases, the SJT verdict served to deflate the expectations of plaintiffs or their attorneys

87. Cf. Posner, supra note 20, at 387 (providing hypothetical example of a summary verdict's potentially coercive influence on the settlement process).

88. See METZloff, supra note 73, at 10-12 (describing Noel v. Cole, No. 86-CVS-2279 (N.C. Super. Ct. Sept. 28, 1987) (Mecklenburg County), in which one of the attorneys felt compelled to proceed with the SJT after having agreed to its use).

89. In fact, the SJT verdict complicated one aspect of the final settlement. The case involved a worker who was killed in a fall at a construction site. The defendants believed they liad a strong contributory negligence claim. The summary jury rejected the defense's claim and awarded plaintiff $\$ 80,000$-well in excess of defendants' $\$ 10,000$ pre-trial offer. In response, the defendants increased their offer, but continued to believe that they liad a strong contributory negligence argument that would fare better at trial where live testimony would be permitted. Based on the verdict, however, plaintiff's worker's compensation carrier asserted a subrogation claim, apparently not understanding its non-binding nature. It took several months to achieve a settlement, in part owing to the need to obtain the worker's compensation carrier's acquiescence. Id. at 9-10 (describing Owenby v. BeverlyGrant, Inc., No. 84-CVS-2886 (N.C. Super. Ct. July 13, 1987) (Buncombe County)).

90. See id. at 12-13 (describing Montgomery v. Lowe's, Inc., No. 87-CVS-1784 (N.C. Super. Ct. Oct. 26, 1987) (Buncombe County), and noting that the attorneys believed that the SJT promoted settlement "by providing an occasion for a responsible official from the inanufacturer to be in direct contact with plaintiff' counsel'). Interestingly, this occurred despite the fact that the defense counsel believed that if the SJT lad proceeded to verdict, the advisory verdict probably would not have been helpful given the limitations of the SJT process in light of the complexity of the case. Id. at 13 . 
about the value of the case, ${ }^{91}$ or to establish a point of reference for future settleinent negotiations despite concerns with or criticisms of the process by one or more parties. ${ }^{92}$

4. Litigant Satisfaction. Based upon comprehensive interviews, ${ }^{93}$ attorney participants and judges expressed enthusiasm about their experiences. ${ }^{94}$ They also reported that the hitigants were generally satisfied; as one attorney noted, "the hitigant had their day in court, and the case was over. They didn't have to worry about it any more. The chents seemed very satisfied." 95 Jurors also reacted favorably to the process. 96

91. In a case involving an injury following a fall at a construction site in which the defendant raised an issue of contributory negligence, the parties were approximately $\$ 100,000$ apart, with the defendant only willing to offer $\$ 5,000$ as a "nuisance value" settleinent. The summary jury found that the plaintiff was contributorily negligent. The plaintiff then agreed to settle for the pre-SJT offer inade by the defendant. Plaintiff's counsel stated that the process was an important step in educating the plaintiff on the value of the case. See id. at 13-14 (describing Caton v. E.L. Scott Roofing Co., No. 86-CVS-10374 (N.C. Super. Ct. May 17, 1988) (Wake County)).

92. In one case, a pro-plaintiff SJT result was perceived by defense counsel as a "worst case scenario" owing to liberal inclusion of evidence that possibly would have been excluded at trial. The case was peculiar. A woinan had been hurt in a car aceident and after receiving emergency treatinent was permitted to go home. She fell at loone, and her family did not provide any immediate assistance, letting her lie on the floor for several days. Eventually, she was hospitalized, and in her suit against the driver of the car, she claimed the expenses associated with the second hospitalization as damages. The defendant attributed these injuries to her fall at home. The summary jury awarded $\$ 10,000$. Following relatively extensive post-SJT discussions, a settlement was reached for $\$ 9000$. See id. at 18-19 (describing Baxter v. Scott, No. 89-CVS-9780 (N.C. Super. Ct. Dec. 14, 1990) (Mecklenburg County)).

93. Attorneys imvolved in all the North Carolina SJTs were interviewed to explore their assessments of various aspects of the program. Because of the small number of SJTs and the variety of formats employed, no efforts lave been inade to quantify the findings.

94. The following quote froin an attorney illustrates the positive comments that were heard:

It was clearly the best [ADR inethod] that I have been involved with so far. Most of these proeedures involve submitting the case to a single arbitrator on oral testimony or through written subinissions. This last procedure is particularly unattractive to ine ... I remain a strong believer in the value of exposing any case to the collective wisdom of twelve jurors for resolution rather than one fact finder whose particular views are not subject to any moderation.

The primary advantage of the process is that it maximizes understanding and the effectiveness of testimony. You can organize testimony far more effectively and persuasively. Second, it gives the client their 'day in court' in a more relaxed and less stressful inanner. Third, it can save tremendous anounts of time and resources for the lawyer, which may translate into less expense for the client. ...

Clients get a better feel (better than a prognosis based on prior experience) of a likely outcoine if tried ... liere's what'll happen if you risk trying this. That's what happened here-it made an inpression. It inakes it easier to tell superiors to write the check.

METzLofF, supra note 73 , at 37.

95. Id.

96. See id. But see id. at 38 (quoting one attorney who indicated that some members of the summary jury were "upset that they had not heard from the plaintiff" and as a result believed that they had not heard "the whole story"). 
Some participants, however, reacted negatively to the procedure. ${ }^{97}$ In at least six cases, one or both attorneys raised significant complaimts as to how the SJT had functioned. These complaints included insufficient time to prepare, unfair use of summarized evidence by opposing counsel, lack of clear guidelines as to what evidence would be permitted, and inability to obtain court rulings on evidentiary issues prior to the summary trial. ${ }^{98}$ Although such criticisms may simply reflect typical implementation problems associated with an expermiental program, the concerns also reveal difficulties inherent im a process that relies primarily on attorney summaries of evidence in heu of hive testimony.

5. SJT and Cost Savings. Most, but not all, of the attorneys surveyed reported that the SJT generated cost savings to them or their chents. ${ }^{99}$ Cost efficiencies were reported with respect to case preparation, with more significant reductions attributable to reduced trial lengths and because witnesses did not have to testify. Although it may seein axiomatic that a shortened trial would reduce costs, this assumption does not necessarily follow. ${ }^{100}$ For example, although the costs associated with conducting the summary trial will alınost certainly be lower than those associated with a traditional trial (due to the reduction in trial length), preparation costs may not be significantly lower because extensive preparation inay still be required for an SJT. In addition, any realized cost savings may be insignificant, especially if the decision to utilize the SJT is

97. The dissenting assessments were well summed up by one attorney:

I didn't like the process. It's an unusual thing for a lawyer to play so many roles in a case. Here, the lawyer was everything - witness, lawyer, expert. Second, the credibility of witnesses can't be determined by witness affidavits. And third, this took more time to prepare, scattering about to get and share affidavits instead of prepping the witnesses and just trying the case.

Id. Others noted that they would have preferred using another form of ADR. For example, one attorney indicated that non-binding arbitration would have been better snited to his case because it would have avoided the additional time and stress associated with preparing for an SJT. See id.

98. See, e.g., id. at 15-17 (describing case in which attorney complained that the guidelines were not definite enough); id. at 12-13 (describing Montgomery v. Lowe's, Inc., No. 89-CVS-1784 (N.C. Super. Ct. Oct. 26, 1987) (Buncombe County), in which evidentiary rules concerning presentation of expert witness testimony were not clearly established, resulting in severe disagreement over the use of videotaped testimony).

99. No effort was made in the study to quantify or verify any cost savings reported by the attorneys.

100. To date, studies have not been able to isolate any cost savings associated with the use of SJTs. See Enslen, supra note 49, at 30 (noting that it is not possible on the basis of current evidence to deternine whether hitigants save money by using SJTs). Several researchers have asked attorueys whether they believed that the process generated cost savings; their responses suggest that modest savings have been achieved in most cases. See Alfini, supra note 4, at 231 (Table 8) (noting that 78\% of attorueys in the voluntary state court program believed that the use of SJT generated cost savings, as compared to $57 \%$ in the mandatory federal court program who reported that they spent more time). 
not made until after expensive discovery is completed. Indeed, there were cases in which the attorneys reported that they spent more time (and thus incurred greater expense) im preparing and trying an SJT than if the case had been tried conventionally. ${ }^{101}$

\section{Understanding the Lack of Use}

The most salient observation drawn from the North Carolina initiative was the limited use of the summary jury process. Despite considerable efforts to publicize the project, to conduct special educational programs, and to commit judicial resources to encourage its use, the number of SJTs conducted fell well below expectations. ${ }^{102}$ For a variety of reasons, translating the federal court's generally positive experience witlı SJTs to the North Carolina state court system proved difficult. ${ }^{103}$ The North Carolina program-which resulted in only about four SJTs being held per year-contributed virtually nothing toward improving the efficient administration of the state court system.

The low level of activity was underscored by the fact that many of the cases submitted to the process were only marginally significant; under the classic SJT theory, the most suitable cases are those disputes

101. See METZLofF, supra note 73, at 41-42. This may be true in part because many of the SJT cases were low-stakes disputes that could have been quickly tried in a conventional manner. $C f$. infra notes 134-37 and accompanying text (discussing preparation time and associated cost savings potentially attributable to the SJT in malpractice cases).

102. Proponents had hoped that at least four SJTs would be conducted within each of the three pilot districts during the first six months. Jane Ruffin, N.C. Lawyers' Committee Tests Summary Jury Trials, RALEIGH NEwS \& OBSERvER, July 28, 1987, at 4C. In fact, a total of only four SJTs were held during this initial period. METzLoff, supra note 73, at A-1. See generally Gary L. Wright, Lawyers Shun Experiment with Faster Trials, CharlotTE ObSERver, Dec. 20, 1987, at 1C (quoting the director of the North Carolima Administrative Office of the Courts as saying that "[n]one of the three districts has lived up to our expectations and hopes"). It was expected that the pace would increase as more attorneys learned about the procedure through ongoing educational efforts or from satisfied attorneys involved in those SJTs that had been conducted. See id. at 3C. In 1988, the first full year of the program, only two SJTs were conducted. METZLOFF, supra note 73, at A-1. In 1989, four SJTs were conducted, two of which were major disputes that involved over a million dollars in potential damages. Id. In 1990, the number of summary jury procedures increased to five cases. Id. Several of these SJTs also involved major disputes, creating a perception that the process was becoming more popular. See generally Michael Dayton, Summary Jury Trials: Gaining Acceptance, N.C. LAW. WKLY., Apr. 2, 1990, at 1.

The Center's research was not directed to determine how often use of an SJT was suggested by either the court or one party but refused by one or both parties. None of the judicial districts involved in the pilot project kept detailed records relating to cases in which SJTs were suggested but ultimately refused. Nonetheless, several attorueys and court administrators interviewed in connection with the Center's research detailed instances of unsuccessful attempts to employ the procedure.

103. Cf. Enslen, supra note 49 , at 32 (noting the uncertainty as to transferability of particular ADR programs to different court systems). 
that will predictably take a week or more to try. ${ }^{104}$ According to the parties' estimates, the majority of the North Carolina SJTs (ten of seventeen cases) could have been tried conventionally in four days or less. A related measure is that almost half of the cases mvolved less than $\$ 50,000$ in potential damages. Selection of soine of these small-stakes cases probably reflected the experimental nature of the program as judges searched for volunteers regardless of whether the dispute fit the standard SJT profile. ${ }^{105}$ By combining the number of small-stakes disputes and the fact that in inost SJTs the parties agreed to make the result binding, one may calculate the number of classic SJTs conducted: ouly two of the seventeen SJTs met the classic profile of a non-binding procedure for a case that would require at least five days to try traditionally. ${ }^{106}$ In short, voluntary demand for the classic SJTs in "appropriate" cases was virtually non-existent.

Understanding why the program failed to achieve its goals is critical in assessing whether other courts-especially state courts-should commit further resources to developing SJT programs and, if so, how future programs should be designed and implemented. Many possible hypotheses could explaim the lack of use, including the following: (1) failure to require mandatory judicial referral of cases; (2) insufficient attorney familiarity with the SJT concept to consider or agree to its use, especially under a voluntary program; ${ }^{107}$ (3) general attorney assessment that SJTs are flawed and therefore of limited use; (4) poor implesnentation of the

104. Most SJT adherents suggest that an SJT is fitting only for those disputes that would take a week or more to try conventionally given the costs of preparation and the possibility that a full trial will subsequently be required. See, e.g., ProviNe, supra note 5, at 70-71; Bremer \& Simmer, supra note 15, at 314. See generally Enslen, supra note 49, at 24 ("Hardly any judges, after some years of experience, would assess a simple two or three day jury trial to summary jury disposition, particularly when other less costly and time consuming ADR techniques are available.").

105. In addition, it reflects program initiatives pursued in Meeklenburg County to encourage use of the process in small-stakes cases. In that county, one judge developed a modified SJT format targeted at cases that ordinarily could be tried in two days. See The All New Summary Jury Trial Procedures, Mecklenburg County Bar CLE Program (1989). The idea was to conduct a two-hour SJT on the Friday before the case was scheduled for trial the following Monday. After obtaining the non-binding verdict, the parties would be faced with speuding additional time preparing for the "real" trial over the weekend, or reaching a settlement based on the new information obtained from the summary jury. As of the cut-off date for the research report, only three SJTs had been conducted under this special program.

106. See METzLofF, supra note 73, at 15-17 (describing Sarris v. Hall, No. 88-CVS-6721 (N.C. Super. Ct. Dec. 8, 1989) (Mecklenburg County)); id. at 12-13 (describing Montgomery v. Lowe's, Inc., No. 87-CVS-1784 (N.C. Super. Ct. Oct. 26, 1987) (Buncombe County)).

107. See Golann, supra note 8, at 499 (stating that SJT is newest and "lcast well-known" of ADR techniques); Martin Klug, Note, The Alternative Dispute Resolution Promotion Act of 1986: $A$ Critical Analysis, 31 ST. Louis U. L.J. 981, 986 (1987) (noting that SJT "has not received much exposure"). 
program; and (5) insufficient number of cases in the state courts that are suited to the process.

Based upon interviews with participating attorneys and court officials, there was no consensus on which theory best explains the low number of referrals. Many blamed lawyers for refusing to experiment with SJTs. Judges responsible for implementing the program regularly cited both attorney mertia, as well as a perceived lack of ability or confidence among attorneys im conducting an SJT with its greater demands on the attorney's forensic skills. ${ }^{108}$ Both attorneys and judges also inentioned general attorney ignorance about the process as a contributing factor. ${ }^{109}$ One defense counsel, who had been rebuffed by plaintiffs' counsel in several attempts to employ a summary jury, noted that plaintiffs' lawyers were generally reluctant to agree to anything that ininimized a defendant's expenses. ${ }^{110}$

Others questioned the progran's implementation. Several participants noted that a particular judge, even if an SJT advocate, would sometimes be assigned to a different district under the state's rotational system for judges or otherwise be unavailable to meet with the parties to explain or promote its use. ${ }^{111}$ Some attorneys questioned whether individual judges had sufficient time, resources, or interest to pronote SJTs effectively. For example, participating judges were not afforded any release time from other judicial duties to promote SJTs. Especially without the option of forcing parties to use the process, judicial efforts to explore the possibility of employing the SJT were potentially unproductive. Others reported that some court officials responsible for impleinenting the program appeared ambivalent about the SJT's benefits. ${ }^{112}$ Moreover, there was confusion regarding the role of the local trial court adininistrator in implementing the program, such as whether that person was expected to

108. As explained by one judge, attorneys did not care for the SJT because it required them to be "more organized than traditional trials. The average attorney will not want to expend this additional effort, especially without assurance that it will finally resolve the dispute." METzLoff, supra note 73, at 40 . This critique suggests that attorneys' abilities are not currently well suited to the types of advocacy skills required in ADR prograins. See Edward F. Sherman, Reshaping the Lawyer's Skills for Court-Supervised ADR, 51 TEX. B.J. 47 (1988).

109. See METZLOFF, supra note 73, at 39-40.

110. An efficient procedure like the SJT:

negates the tool they use to hold defense counsel's feet to the fire-litigation is used as a settlement tool. The summary jury trial diminishes the expenses of the [defendant] and with it plaintiff counsel's leverage to force settlement is decreased, because he uses the threat of litigation to increase the attractiveness and value of settlement.

Id. at 41 .

111. See id. at 40.

112. See id. 
screen cases for appropriate SJT candidates or actively try to encourage attorneys to employ the process. ${ }^{113}$

A third set of comments suggested that the low level of interest was primarily a function of the lack of suitable cases in the state court system. ${ }^{14}$ It may well be that the potential pool of appropriate SJT candidates-defined here simply as civil cases that require a week or inore to try conventionally - was fairly small in the state court settimg. For example, one trial court administrator indicated that in his district there were probably less than five cases a year fitting the classic profile. ${ }^{115}$ In coinparison, federal dockets are comprised of a much higher number and concentration of potentially lengthy trial cases, ${ }^{116}$ making the potential benefits offered by an active SJT program correspondingly greater.

Moreover, there are other significant differences between the federal and state systems that relate to court-1nanageinent practices. In particular, the assignment of cases to particular judges for pre-trial management, as well as the development of aggressive case manageinent under Rule 16 of the Federal Rules of Civil Procedure, ${ }^{117}$ make it more likely that federal judges will be in a better position to recognize potential SJT candidates than their state court counterparts. ${ }^{118}$ State court judges are accordingly less likely to have sufficient information to assess the utility of SJTs even if a consensus existed as to the type of cases in which it was

113. See id.

114. See id.

115. Id.

116. Posner has noted that $10.9 \%$ (constituting over 2000 trials) of the federal court docket were civil jury trials lasting at least four days. See Posner, supra note 20, at 383. Posner suggests that even with this profile, the SJT would not noticeably impact the federal courts' rate of case disposition even if regularly used. See id.

117. See FED. R. CIV. P. 16. For discussions of the evolution of aggressive pre-trial management (of which the development of the SJT is an example), see Robert F. Peekham, The Federal Judge as a Case Manager: The New Role in Guiding a Case from Filing to Disposition, 69 CAL. L. REV. 770 (1981); Judith Resnick; Managerial Judges, 96 HARV. L. REv. 374, 386 (1982).

118. In North Carohina, due in large part to judicial rotation among districts, cases are not regularly assigued to a particular judge for pre-trial management. Moreover, the large number of case filings precludes extensive pre-trial management of the type that would permit a judge to become sufficiently familiar with the case to assess its potential utility in terms of ordermg an SJT. Determining appropriate cases is apparently a function not only of the legal and factual issues involved in a case, but also of the relationship of the parties and the attorneys. See supra notes 45-46 and accompanying text. But see Peterson, supra note 24, at 62 (questioning whether federal judges are well positioned to assess whether cases are appropriate for the SJT process because "[h]eavy caseloads often prevent them from really understanding the case and the parties"). Case management styles are potentially important as many descriptions of the SJT process emphasize the benefits of educating the parties regarding the use of an SJT. See QUARLES, supra note 17, at 237-38 (interview with Judge Lanbros describing how he introduces the possibility of SJT during initial discovery conferences). 
best employed. Fmally, the SJT process may be more appealing to litigants in courts with substantial case backlogs, especially if the SJT provides a means to jump ahead of other cases in the trial queue. Because most North Carolina courts were able to try cases soon after the attorneys indicated that the case was ready, this potential incentive was lacking.

Another oft-stated reason for the low imterest level in the SJT expressed by both participating and non-participating attorneys was that the process was unfair or biased. ${ }^{119}$ To be sure, soine of these opimions may simply reflect post-SJT rationalization of unexpected results by losmg litigants. The number of coinments received, however, were sufficiently numerous as to inerit consideration.

Most of the attorneys expressing a fairness concern believed that the SJT was biased in favor of plaintiffs. 120 Supporting or perhaps creating this view was the presence of two very large summary verdicts rendered in favor of plaintiffs in contested hability cases. These verdicts-one for $\$ 8$ million and the other for $\$ 3.65$ million-seen especially high given that the settlements reached following the SJT were much lower. In neither case was determining damages the primary issue. In one case, the defendant-owing to a pre-existing high/low agreement-decided as a tactical inatter not to present any evidence regarding damages; ${ }^{121}$ in the other, the issue was whether the corporate defendant had neghigently entrusted a coinpany vehicle to an einployee known to have had a drinking

119. To date there has been little analysis or discussion suggesting that the SJT favors either plaintiffs or defendants. It has been noted that the SJT's compressed format is likely to result in more inconsistent decisions, but it does not necessarily follow from this fact that the SJT format is biased in favor of plaintiffs or defendants. See Golann, supra note 8, at 518 n.128. It has been suggested, however, that the SJT'S compressed format tends to emphasize the importance of the jury's imitial impressions of the evidence, thus giving the first speaker-usually the plaintiff's attorney-a possible advantage. See Rowland, supra note 6, at 1095. See generally METzLoff, supra note 73, at 38 (quoting an attorney claiming that SJT's abbreviated format gives an unfair advantage to whichever side was able to create a favorable initial inipression). Cf. Lon L. Fuller, The Forms and Limits of Adjudication, 92 HARV. L. REV. 353, 383 (1978) (noting the "natural liuman tendency to judge too swiftly in terms of the faniliar that whicl is not yet fully known" and observing that the adversarial approach tends to keep an issue unresolved and provide "timc to explorc all of [the issue's] peculiarities and nuances").

Alfini noted that plaintiffs prevailed in $86 \%$ - a remarkably high percentage-of the SJTs studied in the Florida state courts. See Alfim, supra note 4, at 225 (Table 3). Ordinarily, one would predict plaintiff success rates of approximately $50 \%$. See infra note 152 . It is quite possible, however, that cases were self-selected to the SJT process primarily because they turned solely on the issue of dainages (such as was observed in most of the North Carolima SJTs) so that the ligh rate of plaintiff success would be anticipated.

120. See Metzloff, supra note 73 , at $40-41$.

121. See id. at 22 n.65 (describing Phillips v. Huffman, No. 88-CVS-2072 (N.C. Super. Ct. May 30, 1989) (Catawba County)). 
problem. ${ }^{122}$ Nonetheless, these awards sounded a strong note of caution to many defense attorneys, leading several to conclude that summary juries tend to overlook the factual issues that, im a longer trial, could lead to a defense verdict. ${ }^{123}$ Indeed, one plaintiff's counsel, frustrated in several efforts to use SJTs by recalcitrant defense attorneys, pointed to "a clear impression in the defense bar that it's geared to plaintiffs," and that "the word is out that the SJT is a plaintiff's vehicle."124

There is evidence, however, that refutes the pro-plaintiff claim. The North Carolina prograin included seven cases in which a binding SJT was used to establish dainages. In those cases, a comparison between the parties' pre-SJT bargaining positions suggests that defendants did well. Specifically, the summary jury's verdict fell within the range of the parties' high/low parameters in only three of the seven cases. ${ }^{125}$ In the remaining four cases, the verdict was below the minimum payinent amount, thus constituting clearly pro-defendant verdicts. Moreover, even in the three cases in which the verdict fell within the settlement range, the verdict was closer to the low end. The number of cases is small, however, and this observation inay reflect case specific factors such as madequate performance by counsel or the setting of unrealistic high/low ranges.

\section{Evaluating the Potential Utility of the Non-Binding SJT: The Medical MalpRactice EXAMPle}

Because few studies of the SJT have been conducted, and because additional examination is apparently limited by the discretionary nature of its intended use, creative research strategies inay be required to further test the SJT's capabilities. One approach would be to examine the pool of trial cases in a particular court systein or area of the law to analyze whether the hitigation issues presented inatch the SJT's supposed strengths. The imsights offered from this vantage point would permit an assessment of the SJT's appropriate role among the inany ADR strategies now available. A focused examination of this type can be inade by

122. See id. at 15-17 (describing Sarris v. Hall, No. 88-CVS-6721 (N.C. Super. Ct. Dec. 8, 1989) (Mecklenburg County)).

123. For example, in one case involving an elderly plaintiff against an out-of-state defendant, the local trial court administrator urged defense counsel to consider the use of an SJT. The attorney refused, noting the reports of the large pro-plaintiff outcomes in other SJT cases. In his view, the procedure's brevity prevented the "normal mitigation of damages" phenomenon that occurs when a jury gets a chancc to recognize the defendant as a "real person." Under this theory, jurors are initially sympathetic to any plaintiff; only after days of observing the parties do the jurors come to harbor doubts about the merits of the plaintiff's suit. See id. at 41.

124. Id.

125. See supra Table 1. 
drawing upon an elaborate study conducted by the Private Adjudication Center of all hitigated medical malpractice disputes filed in North Carolina during a three-year period. ${ }^{26}$

Owing to its federal court origins, the SJT has not been regularly employed im malpractice cases, ${ }^{127}$ which are predominately filed in state court. ${ }^{128}$ If the process is to play a major role in state courts, however, inalpractice disputes would likely be a prime target. Malpractice trials are on average lengthier than other civil trials ${ }^{129}$ and typically comprise a significant portion of most state court trial dockets. ${ }^{130}$ If the benefits of the classic SJT cannot be demonstrated with respect to inedical malpractice cases which are clearly among the most important category of "highstakes" civil disputes regularly hitigated in the state courts, then its general role should be questioned as well. ${ }^{131}$

126. For a description of the study's methodology, see Thomas B. Metzloff, Resolving Malpractice Disputes: Imaging the Jury's Shadow, LAw \& ConTEMP. ProBs., Winter 1991, at 43, 48-51. The study examined all malpractice cases filed between July 1, 1984 and June 30, 1987 in the North Carolina state and federal courts. Overall, the study identified 895 malpractice cases, which generated 118 trials.

127. There is apparently only a single official reference to the use of a non-binding SJT in a medical malpractice case. See Lockhart v. Patel, 115 F.R.D. 44 (E.D. Ky. 1987); see also Alfini, supra note 4, at 221 (Table 1) (indicating that there were no medical malpractice cases among 43 SJTs studied in the Florida state court program). The existing hiterature does not explicitly discuss the SJT's suitability to malpractice claims, although SJT proponents tend not to be very specific about the types of cases amenable to the process. See supra note 14.

128. See Metzloff, supra note 126, at $107 \mathrm{n} .204$ (stating that less than three percent of malpractice claims in North Carolina were filed in the federal courts). Sometimes malpractice litigation can be filed in federal court under the court's diversity jurisdiction, or, if the claim is against a governmental entity or enployee, under the Federal Tort Claims Act, 28 U.S.C. $§ 1346(b)$ (1988).

129. See National Center for State Courts, ON Trial: The Length of Civil and CR1MINAL TR1ALS 9-10 (1988) (noting in study of trial lengths in three jurisdictions that the average length of professional malpractice trials was 17 hours, as opposed to 13 hours for average civil trials).

130. See Stephen Damiels \& Lori Andrews, The Shadow of the Law: Jury Decisions in Obstetrics and Gynecology Cases, in 2 Medical Professional Liability aNd the DeLIVERY OF ObSTETRICAL CARE 161, 169-72 (Victoria P. Rostow \& Roger J. Bulger eds., 1989) (Table 2) (reporting that malpractice verdicts during five-year study on average comprised $7.7 \%$ of total state court verdicts).

131. One pervasive issue in the malpractice context is the concern that inany plaintiffs with meritorious claims are unable for a variety of rcasons to access the litigation system. See PaUL C. Weiler, Medical Malpractice ON Trial 12-14 (1991) (detailing existing evidence on the incidence of medically negligent care and the relatively low rates of patients seeking compensation). A frequent goal of recent malpractice ADR proposals-even those forwarded by the medical establishment-is to improve claimant access to the malpractice compensation system. See, e.g., Kirk B. Johnson et al., A Fault-Based Administrative Alternative for Resolving Medical Malpractice Claims, 42 VAND. L. REv. 1365, 1390 (1989) (describing American Medical Association's proposal that encourages greater access by simplifying filing of claims and by providing counsel to claimants); see also WEILER, supra, at 159 ("The serious failing in our civil justice system is that it is unable to identify and redress such a high proportion of the potentially valid suits that patients are entitled to bring."). The SJT, which relies on the traditional litigation process up to the point when the case is ready for trial, does not even in theory address this reforn goal. 
A key inquiry is whether the SJT is likely to produce cost savings for the parties. Because the SJT is designed to be employed only after the parties have completed or conducted substantial discovery, cost savings will prove ephemeral if discovery costs represent the bulk of the hitigants' expenses. According to my study of defense expenditures in malpractice trials, however, meaningful cost savings are possible in the malpractice context because the combined costs of conducting and preparing for trial exceed the costs of discovery. ${ }^{132}$ Assuming that SJTs would decrease trial length (and thereby trial expenses) by seventy-five percent, and that the procedure would also generate some savings with respect to trial preparation, classic SJTs in the malpractice context could potentially reduce litigation costs by approximately thirty percent. ${ }^{133}$

Realizing these savings, however, may prove problematic. To achieve the maximum reduction, an SJT-inspired settlement would have to occur soon after the hearing, with minimal post-SJT negotiations. If, for example, the parties were required to undertake preparations for a subsequent conventional trial, the cost savings offered by the SJT could decrease by more than one-third, even if the real trial were avoided by a last-minute settleinent. ${ }^{134}$ If the conventional trial were in fact conducted, the savings would evaporate and the parties would likely expend at least ten percent more than if the SJT had not taken place, even assuming that the conventional trial were soinewhat shorter as a fringe

132. In an analysis of cost expenditure patterns in 17 inalpractice trials, defense costs averaged $\$ 46,515$. Metzloff, supra note 126 , at $56-57$ n.45. Of this, discovery costs averaged $\$ 21,890$ (47\% of the total), pre-trial preparation expenses (which included those costs incurred within approximately three weeks of the scheduled trial date) averaged $\$ 10,090$ (22\% of the total), and direct trial expenses averaged $\$ 14,535$ (31\% of the total). Id. Combined trial preparation and trial expensesrepreseuting the marginal cost of trial-averaged $\$ 24,625$ (53\% of the total). Id.

133. If the SJT reduced trial length by $75 \%$, the cost savings (assuming that expense was solely a function of trial length) iu an "average" malpractice trial, see supra note 132, would equal $\$ 10,900$ ( $\$ 14,535$ multiplied by .75). In addition, assuming that traditional trial preparation costs could be reduced by $25 \%$, an additional savings of $\$ 2520$ would be realized $(\$ 10,090$ multiplied by .25$)$. On the issue of whether SJT preparatiou time is in fact less extensive, see Maatman, supra note 5, at 481 (suggesting that SJT preparation requirements are substantial). The combined savings of $\$ 13,420$ constitutes $29 \%$ of the total average defense costs as set forth supra, note 132 . Expressed differently, the estimated cost of preparing for and conducting the SJT would equal $\$ 11,160$, consisting of preparation costs of $\$ 7570$ and trial costs of $\$ 3590$ (assuming that the time and expenses involved with post-SJT negotiations are minimal).

134. If preparation efforts equaled half of what ordinarily would have been required for trial (based upon the assumption that preparing for the SJT reduced the need to prepare for the traditional trial), additional preparatiou expenses would total $\$ 5045$ (one half of $\$ 10,090$ as set forth supra in note 132). Even if the settlement occurred at that point (so that proponents could claim that the SIT was successful), the cost savings would have been reduced from $\$ 13,420$ to $\$ 8,375$, which represents only an $18 \%$ cost savings. As a practical inatter, it is unclear how preparing for the SJT will serve to reduce preparation for the traditional trial that consists to a large degree of meeting with witnesses to review potential testimony-a method of preparation not required for the SJT. 
benefit of having conducted the SJT. ${ }^{135}$ This cost analysis deinonstrates the critical importance of understanding precisely how the SJT leads to settlement and when those settlements are likely to occur.

The study of malpractice disputes also serves to identify another clear risk associated with the classic SJT prototype. Its proponents assume that judges can ably identify cases for SJT referral that will not settle otherwise. In practice, selecting the truly intractable cases is likely to prove difficult because inany of the malpractice cases in which trial appears imminent are actually dismissed or settled before the trial begins. During the three-year period covered by the study, approximately 100 inalpractice cases were tried to verdict. About the same number were settled in the period immediately preceding trial. ${ }^{136}$ As a result, the pool of cases that appeared to be headed for trial was at least twice as large as the number of cases that in fact were tried to verdict. The existence of this large pool creates a substantial risk that judges who mandate the use of SJTs will err and select cases that would have settled on their own accord, thus seriously threatening to increase the litigants' costs and perhaps increase the overall level of judicial mvolveinent-a result clearly at odds with traditional justifications for the procedure. ${ }^{137}$ The large number of "last minute" settlements also strongly indicates that a more pressing goal is the development of ADR methods that offer the promise

135. SJT proponents have claimed that the conventional trial would be shorter because the SJT would permit a narrowing of the issues, see supra note 17 , although there is no evidence that this effect in fact occurs. Because many of the events that occur at a traditional trial-such as selecting and instructing jurors, and affording the jury an opportunity to deliberate-would be unaffected by what transpired at the SJT, reductions in the lengths of conventional trials may be minimal. Even assuming a liberal $25 \%$ reduction in both trial preparation and trial length associated with a postSJT conventional trial, the costs for the "real" trial would be $\$ 18,470$ (total cost of trial and trial preparation of $\$ 24,625$, as set forth in note 132 , multiplied by .75 ). When added to the discovery costs $(\$ 21,890)$, plus the costs of preparing for and conducting the SJT $(\$ 11,160)$ as estimated supra in note 133 , the total cost for resolving the case would be $\$ 51,520$, an $11 \%$ increase over the costs of simply conducting the traditional trial.

136. Information on the timing of settlements was obtained in 418 settled cases. Of that group, 106 were settled in the period immediately preceding trial. It is also likely that a substantial number of cases were dismissed by plaintiff' attorneys immediately prior to trial, which would result in an even larger number of cases that appeared to be headed toward trial. In addition, 18 trial cases were disımissed by the plaintiff or settled prior to receipt of the verdict. Metzloff, supra note 126, at 51.

137. The precise impact would depend on several factors, most notably the relative likelihood that a case scheduled for an SJT would settle as compared to a case scheduled for a regular trial, a question on which there is no evidence. This concern might be overcome if it could be demonstrated that judges were adept at selecting from among the larger pool of trial cases. There is no evidence, however, that they possess this talent-especially in state courts-where pre-trial management efforts are less extensive on average than in the federal courts. It is also possible to argue that the judicial system might benefit from increasing the combined total of SJTs and trials because the overall quality of settlements may be improved as a result of conducting SJTs even in cases that would have settled on their own accord. As with many other issues, there is no evidence suggesting that SJT-inspired settlements are qualitatively improved. See Galanter, supra note 35. 
of proinoting earlier settlements before significant trial preparation expenses are incurred (a goal that is, at best, only indirectly served by the SJT).

Putting aside the concern of whether the SJT offers costs savings, as well as the difficulty of identifying truly intractable cases, the question reinains whether the classic SJT would be profitably employed in those inalpractice cases that are in fact tried conventionally. Answering this question requires a more detailed understanding of the nature of malpractice trials. A rich body of literature on the trial selection process predicts that trial cases do not represent a random sample of litigated cases because clear liability or non-liability cases, along witl sinall-stakes cases in which trial is not cost-effective, are more likely to be settled or dropped, leaving contested disputes that involve large potential damages overrepresented in the trial sample. ${ }^{138}$ As observed in the study, lowever, the actual profile of malpractice trials differs in two important dinensions from this general prediction. First, the majority of inalpractice trials involved cases with relatively small-stakes: Over one-half of all malpractice trials involved likely potential damages of less than $\$ 100,000.139$ Second, contrary to the expectation that close liability disputes would most likely be tried, a large coliort of trial cases imvolved weak claims in which the defendant malpractice insurers, supported by expert opinion, believed that the odds of the defendants prevailing were high. ${ }^{140}$ In coinbination, the observed trial subset consisted to a surprising degree of weak plaintiff's claims involving relatively sinall stakes.

How often will the SJT be a suitable ADR response given this profile? In two respects, this pool is comprised of disputes that would be deeined inappropriate even by most SJT proponents. First, more than forty percent of the inalpractice cases were tried in less than five days, ${ }^{141}$ the minimum length considered by most observers as a thresliold for application of the SJT method. ${ }^{142}$ Second, contrary to the common assumption that malpractice cases largely turn on complex medical testiniony offered by opposing expert witnesses, approximately twenty

138. See, e.g., Theodore Eisenberg, Testing the Selection Effect: $A$ New Theoretical Framework with Empirical Tests, 19 J. LEGal Stud. 337 (1990); George L. Priest \& Benjamin Klein, The Selection of Disputes for Litigation, 13 J. LEGAL STUD. 1 (1984).

139. Metzloff, supra note 126 , at 70 (Table 7) (reporting that $61 \%$ of sampled trial cases involved claims for less than $\$ 100,000$ based upon the midpoints of insurers' estimates of likely damages if plaintiff prevailed).

140. Id. at 69 (Table 6) (reporting that $41.7 \%$ of subset of trial claims were disputes in which the insurers expected to wim on the merits).

141. Id. at 50 (Table 1) (reporting that $45.9 \%$ of malpractice trials were conducted in four days or less).

142. See supra note 104. 
percent of the malpractice trials presented significant factual issues that turned on a jury's assessment of witness credibility - cases generally acknowledged to be incompatible with the SJT process. ${ }^{143}$ In combination, these two factors suggest that, at best, only about half of the malpractice cases actually benig tried would meet these initial screening criteria.

An examination of the remaining malpractice trials suggests two potentially appealing categories in which the SJT could be profitably en1ployed: cases that present difficult damage valuation issues and cases that involve weak plaintiffs' claims. With respect to the first category, it is clear that assessing damages presents nuajor difficulties in the nualpractice context-several malpractice trials turned primarily on danuages issues; many others presented sharp disagreements regarding how to value damages. ${ }^{144}$ This observation suggests potentially fertile ground for the use of SJTs because its proponents have specifically clainied that such disputes are amenable to the process. ${ }^{145}$

In fact, however, there is reason to question its utility in valuing damages in the malpractice setting. A major criticism of the current litigation system as applied to malpractice cases is that the jury is unable to value damages consistently given the amorphous concept of pain and suffering. ${ }^{146}$ Employmg an SJT does not address these serious criticisms of how lay jurors award daniages. Partially as a result of the few occasions in which juries in fact award damages in malpractice cases, ${ }^{147}$ the evidence indicates that jury damages awards are difficult to predict. Even assuming that a summary jury could make a decision on damages that is of comparable quality to that of a regular jury (thus making the SJT a suitable substitute for a full trial), there remanis legitimate and serious concerns about the quahty of conventional malpractice juries' determinations with respect to awarding damages. In fact, the use of evidentiary

143. See supra note 21.

144. See Metzloff, supra note 126 , at 52 .

145. See Provine, supra note 5, at 69 ("The most obvious application is the original one, the relatively simple personal mjury action where liability is likely but the amount of damages a jury might award is difficult to predict.").

146. See Randall R. Bovbjerg et al., Juries and Justice: Are Malpractice and Other Personal Injuries Created Equal?, LAW \& CoNTEMP. PROBs., Winter 1991, at 5; Randall R. Bovbjerg et al., Valuing Life and Limb in Tort: Scheduling "Pain and Suffering," 83 Nw. U. L. REV. 908 (1989); see also WEILER, supra note 131, at 47-61 (describing difficulties with determining damages in malpractice cases and discussing proposed solutions).

147. See Metzloff, supra note 126, at 84 (noting that in three-year sample of malpractice cases in North Carolina, juries were required to award damages in only 17 cases). The low number of damage awards partially reflects the fact that malpractice plaintiffs prevail in a low percentage of trials. 
summaries and other procedural shortcuts suggests that summary jury decisions on average would be even less consistent. ${ }^{148}$

Another area in which it has been suggested that the SJT is usefully employed is in weak hability cases as a means of convincing plaintiffs that their claims lack inerit. ${ }^{49}$ This potential apphication could have special appeal in the malpractice context-it has long been assumed that a high percentage of malpractice disputes are non-ineritorious and that existing procedural methods for screening disputes, such as the inotion for summary judgment, are ineffective. ${ }^{150}$ Our study provides supporting evidence: Forty per cent of all hitigated inalpractice claims resulted in no payment to the plaintiffs. ${ }^{151}$ More directly relevant to the potential use of the SJT is the low rate of plaintiffs' victories at trial. Although existing theory predicts that trial outcomes should tend to result in plaintiffs and defendants winning at approximately equal rates, ${ }^{152}$ it has been

148. Cf. Rowland, supra note 6 , at $1082-86$ (discussing factors that may account for different results in SJT proceedings). The fact that SJTs often use small juries may be a factor; there is evidence that smaller juries render less consistent decisions than do larger ones. See Paul D. Carrington, The Seventh Amendment: Some Bicentennial Reflections, 1990 U. CHI. LEGAL F. 33, 51-56 (discussing the impact of reductions in jury size).

149. See, e.g., Provine, supra note 5, at 69 (noting that an SJT "may encourage the plaintiff to take stock of the legal strength of the clain and reduce the demand for damages accordingly, inaking eventual settlement inore likely"). See generally Reder, supra note 46, at 227 \& n.48 (suggesting use of a neutral pre-trial evaluation of malpractice claims to overcome plaintiffs' attorneys' tendency to overstate or overestinate value of the case).

150. See Patricia M. Danzon, Medical Malpractice: Theory, Evidence and Public PoLICY 18 (1985) (noting "widespread belief that inost inalpractice clains simply reflect the unrealistic expectations of hitigious patients, who sue whenever the results of health care intervention are less than perfect"); Sheila L. Birnbaum, Physicians Counterattack: Liability of Lawyers for Instituting Unjustifled Medical Malpractice Actions, 45 Fordham L. REv. 1003, 1004 (1977) ("Many physicians believe that the inedical inalpractice insurance crisis has, in large part, been caused by overzealous and unethical attorneys who institute groundless inalpractice suits.") See generally Thonas B. Metzloff, Researching Litigation: The Medical Malpractice Example, LAw \& CoNTEMP. ProbS., Autumn 1988, at 199, 203-16.

151. In the study, the plaintiff did not obtain any recovery in approximately 360 out of the 895 cases sampled (or alinost exactly $40 \%$ ). Metzloff, supra note 126 , at 113 n.232. Other recent empirical studies refiect a similar percentage. See Frederick W. Cheney et al., Standard of Care and Anesthesia Liability, 261 JAMA 1599, 1601 (1989) (noting that $46 \%$ of anesthesia-related malpractice claims reviewed by inedical experts were found to have involved appropriate inedical care); Henry S. Farber \& Michelle J. White, Medical Malpractice: An Empirical Examination of the Litigation Process, 22 RAND J. EcoN. 199 (1991) (noting that in sample of 252 claims against a single hospital, $36.5 \%$ were either dropped by plaintiffs or dismissed by the court, while an additional $5.2 \%$ of the claims went to trial and resulted in a verdict in favor of the hospital).

152. For elaborate discussions of the so-called " $50 \%$ hypothesis," see Eisenberg, supra note 138, at 337-51; Priest \& Klein, supra note 138, at 17-24. The theory assumes that because opposing attorneys are equally adept at analyzing disputes, the likelihood of evaluation errors will be evenly distributed anong plaintiffs and defendants. Assuming further that both parties are risk neutral and that the stakes of the litigation are syıninetrical (nneaning that no party is inore or less prone to go to trial because of factors such as protecting reputation or insisting upon their day in court), plaintiffs and defendants should win with equal frequency. 
regularly observed that medical malpractice plaintiffs prevail much less frequently, ${ }^{153}$ thus suggesting that the problem of weak plaintiffs' cases going to trial is especially prevalent for malpractice suits.

Focusing the SJT on potentially low-merit claims raises difficult problems, however. First, many malpractice cases are dismissed prior to trial pursuant to voluntary dismissals or judicial grants of motions for summary judgment. ${ }^{154}$ Defendants are certainly likely to prefer an early dismissal or the finality of a summary judgment over a non-binding ADR proceeding occurring late in the game, even if the result was the saine. If SJTs were inade routinely available, some plaintiffs might elect not to dismiss their case early and instead seek a referral to an SJT for a chance to obtain a favorable result that would predictably increase the case's settlement value. ${ }^{155}$ Similarly, some judges might elect to require an SJT in heu of granting a summary judgment motion. Second, requiring defendants to present their evidence and strategy in a non-binding setting provides an arguably unfair advantage to unprepared plaintiffs' attorneys, who may benefit from such disclosures should the case be subsequently resolved in a traditional trial. Malpractice insurers often choose to proceed to trial in part due to their determination that the plaintiff's attorney is unable to present the case effectively. ${ }^{156}$ In such cases, the malpractice defendant might strongly prefer to skirt the SJT and proceed immediately with the binding trial. Another concern is that several of the ostensibly "weak" plaintiffs' claims involve disputes that could be

153. In the North Carolina study, plaintiffs prevailed in less than $20 \%$ of the cases. Metzloff, supra note 126, at 50-53. Other studies have also reported low rates of plaintiff success, although not as dramatic as observed in North Carolina. See Eisenberg, supra note 138, at 357 (Table A1) (noting a $38 \%$ plaintiff success rate in sample of 697 federal court malpractice trials); F. Patrick Hubbard, "Patterns" in Civil Jury Verdicts in the State Circuit Courts of South Carolina: 1976-1985, 38 S.C. L. REV. 699, 730-32 (Table 9) (1987) (reporting a 38\% success rate for plaintiffs in malpractice trials); Orley H. Lindgren et al., Medical Malpractice Risk Management Early Warning Systems, LAw \& CONTEMP. Probs., Spring 1991, at 23, 37 (noting that plaintiffs prevailed in only $16 \%$ of claims brought to trial against group of California hospitals).

154. Plaintiffs' attorneys appear to reassess regularly the merits of their claims after conducting some discovery, and may drop weak claims. See Farber \& White, supra note 151, at 11 (Table 1) (noting that of 51 cases dropped or dismissed before trial, 44 were dropped relatively early in the process prior to a non-binding, mandatory ADR procedure). In the North Carolina study, 47 cases (representing approximately five percent of the total claims) were dismissed on defendant's motion for summary judgment. In addition, a number of other cases were dropped by plaintiffs prior to the summary judgment hearing as a result of the filing of the inotion. Metzloff, supra note 126, at 50 .

155. The question can certainly be asked whether the SJT is the preferred ADR approach for identifying non-meritorious cases. In the malpractice context, pre-trial screening panels have been employed in a number of states to provide an early review-often before the lawsuit is filed in court—primarily as a means of identifying non-meritorious cases. For a current review of the development and use of screening panels, see Jean A. Macchiaroli, Medical Malpractice Screening Panels: Proposed Model Legislation to Cure Judicial Ills, 58 GEo. WASH. L. REV. 181 (1990).

156. See Metzloff, supra note 126, at 75-76. 
tried conventionally in only a few days with modest expenses. This point again raises the question of whether the higants would not simply prefer a traditional trial; the best dispute resolution strategy may simply be to ensure an early trial date.

A remaining possible justification to adopt the SJT in malpractice cases would be if these cases frequently presented situations in which the SJT's supposed "party enlightenment" effects would prove beneficial. But any possible benefits under this theory are unlikely froin the defendant's perspective. Defense strategy is usually established by malpractice insurers who, as repeat players in the hitigation system, ${ }^{157}$ are sufficiently adept at analyzing disputes and assessing hitigation risks so that they would not be expected to require or even value the insights offered by summary juries. With respect to the defendant doctors, it is extremely unlikely that they would value the opimions of lay jurors; the medical profession has long been on record as passionately preferring the development of ADR approaches that utilize more expert decisionmakers. ${ }^{158}$ The situation may be shightly different froin the plaintiffs' perspective-it is possible that a few plaintiffs could benefit from the cathartic effect of a summary jury and, as a result, become more inclined to settle. ${ }^{159}$

In sum, a careful assessment of current malpractice trials demonstrates that classic SJTs could at best play a sporadic and incidental role. Although cost savings are possible, significant savings will occur only if the SJT results in prompt settlements. Moreover, because of the large number of malpractice cases that are dropped or settled immediately preceding trial, there is a substantial risk that referring a dispute to an SJT will increase hitigant costs or court involvement. Due to a preponderance

157. See Marc Galanter, Why the "Haves" Come Out Ahead: Speculations on the Limits of Legal Change, 9 LAw \& Soc'x. REv. 95, 98-103 (1974) (discussing special attributes of "repeat players" in litigation process).

158. See, e.g., American Medical Ass'n, A Proposed Alternative to the Civil Justice SySTEM For Resolving Medical Liabilrty Disputes: A Fault-Based, Administrative SYSTEM 3-11 (1988) (noting problems with juries); Johnson, supra note 131, at 1370 ("[J]uries cannot evaluate independently the expert testimony almost always introduced in malpractice cases ...."); see also F. Patrick Hubbard, The Physicians' Point of View Concerning Medical Malpractice: A Sociological Perspective on the Symbolic Importance of "Tort Reform," 23 GA. L. REV. 295, 323 n.110 (1989) (noting that the SJT is "apparently . . . viewed as a matter of trial procedure in general and usually ... not cousidered by proponents of [malpractice] 'tort reform' "). The possibility that individual doctors may be motivated by a desire to seek trial to obtain vindication has been postulated, although how often such desires are in fact made known or given credence by insurers is unclear. See Metzloff, supra note 126, at 77-79; see also Samuel R. Gross \& Kent K. Syverud, Getting to No: A Study of Settlement Negotiations and the Selection of Cases for Trial, 90 MrCH. L. REV. 319, 360-66 (1991). Certainly, there has been no suggestion that doctors seek vindication by lay juries; it is far more likely that they would prefer to seek vindication from other medical professionals.

159. Some evidence suggests that a few plaintiffs may insist upon trial to obtain a chance at vindication even over the objeetion of their counsel. See Metzloff, supra note 126, at 79-80. 
of cases that can be tried quickly or present witness credibility issues, the SJT is only potentially suitable in less than one-half of the current malpractice trials. Even in those cases where the SJT is thought to be appropriate-for determining damages or forcing plaintiffs to consider the weakness of their cases-serious questions remain as to whether the SJT offers a useful, much less a preferred, $A D R$ approach.

\section{RETHINkING THE SUMmaRy JURY TRIAL}

In light of the foregoing analyses, the key question posited at the beginning of this Article relnains: What is the appropriate role of the SJT in developing a comprehensive ADR strategy? Proponents of the classic SJT would likely assert that the North Carolina experience was disappointing in terms of the low incidence of use, and that the experience thus confirms that litigants will either not think to einploy the process or that one party will block its use absent judicial compulsion. ${ }^{160}$ The suggested solution would be apparent: To reap the SJT's potential benefits to the court system, the judiciary inust be einpowered to mandate its use. Yet, this assessinent and prescription for reform are directly challenged by the analysis of the inalpractice context presented in Part III, which deinonstrated that the classic SJT's potential contributions are inarginal or even counterproductive. The evidence also raised an issue as to whether the SJT process is well suited for use in state courts. If these negative observations are valid, what role, if any, can the SJT play?

\section{A. Revising the Summary Jury Concept: The North Carolina Approach}

Several factors coinbined to suggest that the North Carolina SJT prograin needed change. The initial decision to limit summary jury proceedings to particular districts seemed an unnecessary restriction; litigants in other districts had expressed interest in einploying summary juries. Of greater concern was the apparent failure of the experimental plan to identify effectively appropriate SJT candidates. It had been anticipated that judges or other court personnel would play the predoininant role; in fact, this task had proven difficult and largely unproductive. It was also recognized that the North Carolina courts had to adopt a policy regarding whether to allow the radical variations in the SJT's format requested by soine litigants. In light of these concerns and the evidence

160. It is generally assumed that voluntary ADR programs suffer from low levels of use either because of attomey or litigant unfamiliarity with the processes involved, the economic motivations of attorneys to maintain the status quo, or the adversarial nature of litigation. See Golann, supra note 8, at 488; Sally E. Merry \& Susan S. Silbey, What Do Plaintiffs Want? Reexamining the Concept of Dispute, 9 JUST. SYS. J. 151, 151-53 (1984). 
presented as to the use of the SJT in North Carolina, policy makers considered, but ultimately rejected, two extreme options: (1) discontinumg the SJT program owing to the lack of demand and the concerns with the quality of the SJT results; and (2) dramatically expanding the scope of the program by affording judges the authority to mandate its use.

Support for eliminating the program was expressed by a few court officials who preferred that the state's efforts be concentrated on more promising ADR methods (most notably, court-ordered arbitration) that appeared better suited to the vast majority of smaller disputes found in the state court system. These officials particularly doubted whether existing clerk staffs could adequately assist im identifying potential SJT candidates and in explaining its benefits to attorneys under a voluntary system. The prevailing view, however, was that because mamtaining an SJT prograin did not place excessive administrative demands on court persounel, there was no reason to prohibit the voluntary use of SJTs even if the level of referrals remained low.

The question of whether to mandate SJTs in North Carolina was more controversial. On one hand, the results demonstrated that numerous obstacles to the voluntary use of SJTs might be overcome by a mandatory program. On the other hand, several factors weighed agamst giving judges the power to compel the use of SJTs. First, the majority of attorneys who had participated in the program, even though favorably disposed toward the process, cautioned against giving state court judges that authority; ${ }^{161}$ even if uninformed, these opimons could not easily be ignored. ${ }^{162}$ Second, the clear differences in the nature of the cases that comprised the respective state and federal court dockets weighed against elevating the SJT to the status of a primary ADR strategy in the state court setting. At best, the SJT appeared well suited to only a small fraction of existing state court claims. Third, a mandatory program could function optimally only if all judges were both familiar with the SJT process and able to analyze its suitability in specific cases. In fact, however, only a few of the state's trial judges had presided in a summary jury proceeding. ${ }^{163}$ Similarly, the relative lack of active pre-trial management in the state courts as compared to the federal courts made state judges

161. See METzLoff, supra note 73, at 46. This expression is consistent with that expressed by attorneys in other state court SJT programs. See Alfini, supra note 4, at 216.

162. Cf. Brunet, supra note 22, at 7 ("The popularity of a particular procedure is a revealing and denionstrable neasurenient."). This cautious attitude exhibited by nost attorneys is soniewhat ironic in light of the sentinient expressed by several pro-SJT judges that the process seeins alınost a "dream come true" for lawyer's because of the latitude the attomey is provided in presenting the facts of the case. See Provine, supra note 5, at 73.

163. See METZLOFF, supra note 73, app. B (reporting that only three sitting superior court judges had presided over SJTs, the others being either private judges or now retired judges). 
less suited to identify appropriate SJT candidates. Finally, permitting judges to mandate its use may tend to limit continued expermientation with summary jury formats, which was widely perceived as a positive feature of the program. ${ }^{164}$

Instead of either eliminating the program or dramatically expanding its scope by affording judges the power to mandate its use, North Carolina decided to restructure the program. The dilemma of how to best utilize the SJT was resolved by the state adopting a unique approach that centered on party-initiated and party-controlled use of summary juries. The North Carolina Supreme Court enacted a rule that encouraged litigants throughout the state to flexibly design an SJT format, specifically invitimg its binding use. The Rule provided as follows:

\section{GENERAL RULE OF PRACTICE 23}

The senior resident superior court judge of any superior court district or a presiding judge unless prohibited by local rule may upon joint motion or consent of all parties order the use of a suniniary jury upon good cause shown and upon such terms and conditions as justice niay require. The order shall describe the terms and conditions proposed for the summary jury proceeding. Such terms and conditions may include: (1) a provision as to the binding or non-binding nature of the summary jury proceedinig; (2) variations in the niethod for selecting jurors; (3) limitations on the amount of time provided for argument and the presentation of witnesses; (4) limitations on the niethod or nianner of presentation of evidence; (5) appointnent of referee to preside over the summary jury trial; (6) setting the date for conducting the summary jury trial; (7) approval of a settlenient agreenient contingent upon the outconie of the summary jury proceeding; or (8) such other niatters as would in the opimion of the court contribute to the fair and efficient resolution of the dispute. The court shall mamtain jurisdiction over the case, and niay, where appropriate, rule on pending inotions. ${ }^{165}$

164. See id. at 43.

165. N.C. R. CT. 23. The Comment, after discussing the history of the program and summarizing the research results discussed here, stated as follows:

[T]his General Rule provides for the use of summary jury trials based upon the voluntary agreenent of the parties, manifested by way of a joint motion to the court. The rule further provides that the authority to approve the request lies with the senior resident superior court judge for the county or judicial district in which the action is pending (or a presiding judge unless prohibited by local rule). The request shall be approved if the court finds that it is in the interest of justice for good cause shown. In this context, good cause relates to a judicial determination that the use of a summary jury trial represents a fair and efficient inethod for pursuing settleinent of the dispute.

The Rule does not authorize a court to mandate the use of a summary jury trial. Nothing in the rule, however, prohibits a judge or other court administrator from raising the possibility of using a sumunary jury trial with the parties during a pre-trial conference or other event and explaining the possible benefits of the process.

The summary jury trials conducted to date in North Carolina have employed a number of innovative techriques. These variations, many of which are detailed in tle 
The Rule rejects certain shibboleths associated with the classic SJT theory. First, the North Carolina approach tacitly relegates the SJT to a subordinate role in the state's evolving ADR strategy. It was generally believed that other ADR approaches-such as the continued expansion of court-ordered arbitration ${ }^{166}$ or the use of inediated settleinent conferences ${ }^{167}$-would be better suited to the institutional goal of reducing caseload pressures. Second, the Rule anticipates that most SJTs would be initiated by the parties, although as made clear in the comment to the Rule, judges or clerk personnel may contmue to facilitate an SJT. Third, the Rule encourages innovative SJT formats by permitting party control over the design of the SJT format-a radical departure from the approach followed by most other courts that have detailed a paradigm SJT model. 168 Instead of defining guidelines for how SJTs should be conducted, the Rule snnply lists design features that the parties could consider.

Finally, and perhaps most significantly, the Rule emphasizes the SJT's potential as a binding process. To date, virtually no discussions of the SJT have given any serious consideration to its potential as a binding

[Center's] report, have ranged from variations on the methods used to select a jury to limitations on the manner $\mathrm{m}$ which evidence is to be presented. In other cases, the parties have requested that the court appoint a referee to preside over the summary jury proceeding. In addition, the parties in several summary jury trials have agreed that the results would be binding, sometimes pursuant to a "high/low agreement" that limits both parties' risk of an aberrant result. The Rule specifically provides that the court has the power to authorize these practices in appropriate cases.

Id. The author drafted the imitial version of the proposed Rule and Comment. See METzLoff, supra note 73, at 44-45. The rule, with minor amendments, was endorsed by the North Carolina Bar Association's Dispute Resolution Committee at its June 14, 1991 meeting and subsequently adopted by the North Carolina Supreme Court on August 14, 1991.

166. See Court-Ordered ARritration, supra note 67. At present, the North Carolina court-ordered arbitration program has a jurisdictional himit of $\$ 15,000$. The Dispute Resolution Committee in its report recommended expanding the jurisdictional limits. See id. at 10. A \$50,000 limit, for example, would have been sufficient to cover six of the SJT cases litigated under the North Carolina experimental program.

167. The North Carolina General Assembly, again at the request of the North Carolina Dispute Resolution Committee, recently enacted legislation that authorized the mandatory use of mediated settlement conferences in high-stakes cases. See 1991 N.C. Adv. Legis. Serv. 207.

168. The only limit on the parties' design was that they must submit their plan to the court for approval. The court is to approve the request if it finds it to be supported by good cause, which requires a judicial determination that the SJT represents a fair and efficient method for pursuing settlement of the dispute. This may often require an assurance that the parties have agreed to limitations on the evidence or taken other steps to ensure an abbreviated trial. One can imagine a situation in which such approval would not be forthcoming. For example, litigants may prefer a closed trial and attempt to obtain that result by renaming a conventional trial as a "summary jury proceeding" by making only marginal adjustments in the trial format and then seeking approval for a closed trial. Such an approach was permitted in Cincinnati Gas \& Elee. Co. v. General Elec. Co., 854 F.2d 900 (6th Cir. 1988), cert. denied, 489 U.S. 1033 (1989). Similarly, litigants inay attempt to jump ahead of a lengthy court backlog by retaining a private judge and making a few modifications so that the trial could be labeled a "summary jury" proceeding. 
procedure; the possibility that hitigants might occasionally agree to make the result binding has been noted, if at all, only as an afterthought. ${ }^{169}$ How often parties in fact opt to inake the result binding or, more importantly, when they should consider the binding option, has not been detailed. Because SJTs are expected to be used in intractable cases, it has perhaps been assumed that the litigants, who by definition are unable to agree on settlement, would be even less likely to agree on a binding ADR process - especially one that entails such a peculiar imitation of the traditional trial process. SJT proponents may simply have concluded that in its present form, the SJT is not sufficiently trustworthy to serve as a bindmg adjudicatory process except in the rare case. ${ }^{170}$ To the surprise of program designers, however, hitigants in North Carolina demonstrated an interest in using the SJT im a bimding format even in high-stakes disputes with contested hability. In light of the Rule's rejections of much of the theory informing the classic SJT, there is a clear need to articulate the conceptual justifications of the SJT as a party-imitiated process and its particular emphasis on its binding use.

\section{B. Justifying the Binding SJT: $A D R$ and the Settlement Process}

The theory supporting a binding SJT ${ }^{171}$ would proceed from a widely different set of operatimg assuinptions than the classic SJT. Instead of speculating as to why certain trial cases fail to settle, the bimding

169. See, e.g., Provine, supra note 5 , at 75 (noting that the SJT process is advisory unless stipulated otherwise); Lambros, supra note 5 , at 52 ("The procedure is nonbinding, unless all parties agree otherwise ...."). A recent comment by an Arizona state court judge has noted the benefits of binding SJTs. See Barry C. Schneider, Summary Jury Trials with Ceilings and Floors, LrTiG., Summer 1991, at 3, 4; cf. Marcus, supra note 5, at $749-50$ (suggesting that it is not surprising that parties may elect to make an SJT binding given the high quality of the process and its use of juries). A few judges have, on occasion, encouraged the parties to consider making the procedure binding. See Negin v. City of Mentor, 601 F. Supp. 1502, 1505 (N.D. Ohio 1985) (suggesting that making the SJT binding would "obviate the need for a formal jury trial while providing a just, expedient, and inexpensive means of resolving [the] dispute."); cf. Associated Pa. Constructors v. Jannetta, 738 F. Supp. 891,895 (M.D. Pa. 1990) (providing that "counsel may stipulate that a consensus verdict of the jury will be deemed a final determmation on the merits and the judginent may be entered thereon by the court, or they may stipulate to any other use of the verdict that will aid in the resolution of the case").

170. Cf. Rowland, supra note 6, at 1079 (noting that parties "electing to stipulate to the verdict of the summary jury may be, in essence, acting within a framework contrary to key goals" of the traditional trial process).

171. Indeed, the differences in purpose and format between a binding SJT and its classic counterpart are so significant that the binding process perhaps deserves a different name. The North Carolina rule intentionally used the term "summary jury procedures" in its title as opposed to the term "summary jury trial" in order to emphasize the Rule's flexibility and to avoid any limitations inherent in the classic process as described in the hiterature. The Center, which provides administrative services to litigants interested in conducting binding SJTs, refers to the binding process as a "jurydetermined settlement," to distinguish it from the classic version. See METZLOFF, supra note 73, at 19-30. For simplicity, this Article will refer only to binding SJTs. For further discussion of the 
SJT's justification would be found in the settlement process itself. To date, commentators have offered a variety of different goals to which ADR programs inight profitably be addressed. In general, ADR procedures serve as supplements to the settlement process by encouraging earher, less costly settlements. ${ }^{172}$ ADR proponents have for the inost part assumed that settlement of higation is inherently desirable. More recently, however, there has been increasing recognition of the fact that the quality of settlements should not be assuined. ${ }^{173}$ Although defining the quality of settlements is difficult, it is almost certainly true that many litigants, because of the high costs and delays of settlement, and the risks associated with a traditional jury trial, are coerced into settling cases that they anight prefer to adjudicate. ${ }^{174}$

Existing settlement theory predicts that both parties will calculate an expected value based upon their estimates of winning, factoring in the costs of litigation. ${ }^{175}$ As a result of the increasing costs of litigation and the uncertainties of trial, the large majority of higants seriously consider settlement. Even so, settleinents do not always occur immediately (or at all) as the parties engage in "hard bargaining" or strategic behavior in attempts to obtain a more advantageous settlement within the likely wide range of economically rational settlement amounts. ${ }^{176}$ Many ADR options are intended to provide signals as to fair settlement figures within this range. ${ }^{177}$

Center's work, see Neil Vidmar \& Jeff Rice, Jury-Determined Settlements and Summary Jury Trials: Observations About Alternative Dispute Resolution in an Adversary Culture, 19 FLA. ST. U. L. REV. 89 (1991).

172. To be sure, the ADR movement is fueled by a variety of goals. For example, many initial adherents to the ADR movement sought to replace the need for formal means of resolving disputes. See Brunet, supra note 22, at 4.

173. See Galanter, supra note 35 , at 84 (Assuring the quality of settlement "is a central task of the administration of justice. It is time to move beyond uncritical celebration and equally uncritical condemnation of settlement and to grapple with the complex dynamics of the various species of settlements in different bargaining arenas.").

174. This same concern has been inanifested in recognition that some of the litigation problems noted may well stem from the lack of adjudicatory capacity See Albert W. Alschuler, Mediation with a Mugger: The Shortage of Adjudicative Services and the Need for a Two-Tier Trial System in Civil Cases, 99 HARv. L. REv. 1808, $1845-49$ (1986); see also Kevin C. McMunigal, The Costs of Settlement: The Impact of Scarcity of Adjudication on Litigating Lawyers, 37 UCLA L. REV. 833 (1990).

175. For a review of the literature, see Robert D. Cooter \& Daniel L. Rubinfeld, Economic Analysis of Legal Disputes and Their Resolution, 27 J. ECON. LITERATURE 1067 (1989). The overlap in the parties' settlement ranges is frequently referred to as the "surplus." See id. at 1078.

176. See, e.g., Galanter, supra note 35 , at 82 (noting that as the settlement ranges expand because of increasing cost of higation, "actors face the problem of how to reach agreement within the settlement range").

177. See id. (noting that increases in settlement brokers and ADR devices "testify] to the increasing deinand for signals to identify points of convergence within the broad settlement ranges created by higher transaction costs"'). 
If increasing costs of litigation and risk of trial are truly creating even greater incentives to settleinent, an appropriate goal for the courts would be to develop ADR inethods that respond to this potentially coercive pressure by offering lower cost adjudications that minimize trial risks. The classic SJT does not respond to this potential ADR goal. It does not seek to control high discovery costs or the risk of aberrant jury verdicts. Instead, it functions by empliasizing (and perliaps overeinphasizing) the risks and expense of the traditional litigation process. For example, the classic SJT requires litigants to complete discovery, which itself represents a major expense of litigation. It also risks (or even invites) aberrant jury results that inay alter the litigants' pre-SJT bargaining positions.

As demonstrated by the Nortl Carolina experience, the SJT could be retargeted to relieve the pressures to settle created by the increasing costs and uncertainty of litigation. Although several ADR methods might address these concerns (such as the voluntary use of binding arbitration), the question is whether it is also appropriate for the courts to pursue the same objectives through an ADR procedure that utilizes the court's unique resource of the jury. In this new formulation, the SJT is not a ineans of "sliunting off" cases lieaded to trial, ${ }^{178}$ but ratler a procedure of clioice for cost-conscious or risk averse litigants. Developing this option is also consistent with the growing evidence that litigants inay prefer soine forn of adjudication as opposed to settleinent. ${ }^{179}$

A restructured SJT could perforn this new role by offering litigants the opportunity to reduce botli the expense of litigation and the risks inherent in the existing jury systein. ${ }^{180}$ The theory of the binding SJT

178. See Rosenberg, supra note 1, at 816-17.

179. See Lind, supra note 48 , at 35-36.

180. The following example illustrates a possible paradigm case in which the litigants might consider the use of a binding SJT. Assume that plaintiff's attorney has filed an obstetrical malpractice claim on behalf of a severely injured infant. Based upon preliminary assessunents by medical reviewers, opposing counsel agrees that the issue of liability is close. Proceeding to trial would be expensive and pose serious-if not intolerable-risks for both parties. One is tempted to refer to the risks of trial as an "all or nothing" proposition, although if one is to give credence to the medical profession's critique of malpractice juries, the risk is even greater because it is claimed that malpractice juries tend to award more than what is deemed fair compensation in other litigation contexts. See supra sources cited in note 146. For the defendant/insurer, the risk is that the jury, perhaps swayed by sympathy for the mjured child, will award a multi-million dollar verdict, possibly well beyond an amount the insurer believes to be fair compensation even assuming liability. For the plaintiff, the risk is that the jury may find for the doctor, perhaps because of a subtle bias in favor of the professional, see Metzloff, supra note 126, at 90 (discussing possibility of bias in favor of doctors in explaining pro-defendant terminations in malpractice cases), resulting not only in no recovery for the seriously injured plaintiff, but also leaving the attorney (or perhaps the client) to absorb the substantial costs of litigation. For the plaintiff, a binding SJT represents trading the possibility of a windfall recovery for the assurance of reduced litigation expenses and avoiding the possibility of a defense verdict. 
rejects the common assumption that the SJT process is intended for cases in which conventional negotiations have failed. ${ }^{181}$ Instead, it seeks a broader role for the process by providing an ADR option for hitigants presently forced to settle, but who would prefer a binding adjudication if the process could be made less expensive and more predictable. A binding SJT approach described here ineets what Judge Posner has referred to as the "rational hitigant" test. ${ }^{182}$ The process allows hitigants to obtain a binding adjudication of their dispute at a reasonable cost without the risks inherent in the current jury systein. ${ }^{183} \mathrm{~A}$ well-designed binding SJT serves three goals: (1) it avoids the possibly expensive and unproductive post-SJT negotiating process (as well as the need to interview jurors after the summary trial to obtain their subjective assessinents of case); (2) it reinoves the distorting impact of an outlying summary jury decision; and (3) it avoids the possibility of an expensive subsequent trial. ${ }^{184}$

To be sure, the courts benefit greatly froin the risk and expense of the trial setting - these factors provide powerful incentives to settle upon which the smooth function of the court systein is thought to depend. ${ }^{185}$

The large case would not be the only one suitable for the binding SJT. One could easily imagine a complex malpractice case with relatively small stakes in which both litigants would prefer a binding SJT primarily to limit hitigation costs. See Metzloff, supra note 126, at 56 (noting that in smallstakes eases, average defense costs were $57 \%$ of the amount in controversy). The point is not that all litigants will prefer this option; many attorneys may continue to press a litigation strategy that attempts to secure advantages by outspending their opponents. Rather, the point is that rcasonable litigants imight prefer to accept an admittedly imperfect decisionmaking process in return for a reduction in hitigation expense and defined litigation risk.

181. See Lambros, supra note 7 , at 798.

182. See Posner, supra note 20, at 367 . Posner stated:

Althouglı emotion and ignorance play a role in litigation, no proposed alternative is likely to work that assnmes, implicitly or exphicitly, that litigants and their lawyers are irrational. Rationality is the dominant although not the only characteristic of behavior in established institutional frameworks administered by professionals, such as that provided by the rules Id. of federal trial procedure.

183. If agreed to early in the process, the approach also offers significant potential cost savings primarily because, unlike the non-binding SJT, it lias the potential for reducing discovery expenses. Beyond that imipact, cost savings may also be realized primarily as a result of shortened trial lengtl and avoiding appeal and other post-trial processes.

184. Posner also suggested that any ADR innovation should inove the legal system in the "right" direction according to broad social policy. Although his particular approach to appropriate social goals focused on reducing litigation, see Posner, supra note 20 , at 386 , other appropriate goals can be articulated. Although the binding SJT cannot be jnstified as a ineans of settling inore cases, it can be jnstified in terms of minimizing total litigation costs.

185. Indeed, Judge Posner has noted, perhaps somewhat facetiously, that the judicial systein might solve its caseload problems by emphasizing the risks and increasing the costs of hitigation. See id. at 387-89.

The binding SJT approach is also at odds with the majority of recent proeedural developnents - of which the classic SJT is a prime example-that have increased judicial control of the litigation process. See Rosenberg, supra note 1, at 819 (noting that virtually every recent procedural change "favors greater judicial control at the expense of hitigant-lawyer autonomy"). Although 
A revised theory of a binding SJT would reject the inherent desirability of this judicially sanctioned game of "chicken," whereby each party speeds to trial in hopes that the other side will veer off and accept a less advantageous settlement. Instead, the binding SJT permits rational litigants to recognize early in the proceeding that they could restructure the race without risking a head-on collision. Although one might question the wisdoin of providing additional opportunities for parties to use a jury in heu of developing ADR inethods that utilize inore expert decisionmakers, ${ }^{186}$ such a developnent is fully supported by the constitutional protections afforded jury decisionmaking and the fact that for soine litigants the jury remams the decisionniaker of choice. ${ }^{187}$ In addition, its impact on the court system is generally a function of what specific form binding SJTs imight take, how often they would be used, and what impact it might have on the overall litigation systen1.

\section{The Format for the Binding SJT. A binding SJT approach of-} fers the potential for significant cost savings to the litigants. Unlike a court's decision to inandate a classic SJT on the eve of trial, the parties' decision to einploy a binding SJT could be made early in the litigation process (indeed perhaps even before suit is filed). ${ }^{188}$ After linnited discovery, the case could be tried in an abbreviated fashion in which various procedural shortcuts-inany borrowed from the classic SJT format such as the use of summarized evidence-could be einployed.

these developments accurately describe the evolution of court-annexed ADR methods, it is not true of privately-initiated ADR methods such as arbitration and mediation. The binding SJT represents a cross-over of these two trends. The process depends upon both the litigants' interest in using the jury in an ADR setting as well as the cooperation of the judiciary given its functional monopoly on the power to summon jurors. See generally Stephan Landsman, The Decline of the Adversary System: How the Rhetoric of Swift and Certain Justice Has Affected Adjudication in American Courts, 29 BUFF. L. REv. 487 (1980) (arguing that the judicial need to remedy court delay seriously undercuts various aspects of the adversarial system).

186. Cf. Posner, supra note 20 (suggesting development of summary bench trials); see also King v. E.F. Hutton \& Co., 117 F.R.D. 2, 11 n.14 (D.D.C. 1987) (noting that parties agreed to subinit summaries of their claims to the magistrate pursuant to a procedure modeled after the SJT in which the magistrate will provide "an objective evaluation, pro and con, to assist the parties in arriving at a reasonable compromise and settlement").

187. The use of the jury in this creative manner also responds to the suggestion of soine coinmentators seeking means to enlarge the jury's involvement im dispute resolution generally. See Marc Galanter, The Civil Jury as Regulator of the Litigation Process, 1990 U. CH1. LEGAL. F. 201, 257 (arguing that existing evidence on the quality of jury performance "invites us to inprove the litigation system by refining and enlarging the use of the civil jury, not by eliminating it").

188. In inalpractice cases, for example, imsurers often subınit claims to outside medical reviewers prior to the actual filing of the suit. Similarly, many experienced plaintiff's lawyers einploy experts to review the claim prior to filing. Accordingly, both litigants may have sufficient information to make an informed judginent of possible settlement ranges. 
Although the precise format of a binding SJT would be subject to negotiation, ${ }^{189}$ there are several predictable differences between it and a classic SJT. The hitigants' goals in formatting the process would be inore broadly defined than in the classic SJT context, where the court-initiated process is largely driven by an interest in shortening trial lengths. For example, because the parties have committed the resolution of their dispute to the process, they may often be interested in providing more information to the summary jury than would be the case with the classic SJT. Serving this interest might entail the limited use of he or videotaped testimony on critical issues. ${ }^{190}$ Although permitting some live testimony does not ensure that a binding SJT would achieve the same level of quality as a full trial, 191 it does overcoine many of the criticisms leveled against the classic SJT. ${ }^{192}$

189. Because the format is not imposed by the court (as is the case with most classic SJTs), the parties will imcur higher transaction costs in terms of establishing the ground rules. Over time, however, it is expected that a number of established formats will be developed either by private ADR providers or by the courts themselves. Variables that the parties could consider include: (1) hmiting time for argument and presentation of evidence; (2) agreeing upon reductions in the number of witnesses; (3) using affidavits, factual summaries, or videotaped evidence; (4) permitting the jurors to take notes or ask questions, see Larry Heur \& Steven D. Penrod, Some Suggestions for the Critical Appraisal of a More Active Jury, 85 Nw. U. L. REv. 226 (1990); (5) abbreviating jury selection procedures; (6) shortening jury instructions; and (7) agreeing upon a procedure for resolving the case in the event of a hung jury. With respect to the last point, a clear risk associated with a traditional trial is the possibility of a hung jury, which requires the litigants to incur the expense and suffer the delays associated with a second trial. A binding SJT agreement should include a method for resolving the case even in the event of a hung jury through the use of some means of averaging individual juror positions.

190. Even proponents of the non-binding SIT have suggested that the use of limited live testimony may benefit the process. See, e.g., Enslen, supra note 49, at 13 ""There is no reason, however, why 'live' witnesses may not testify or be extended a brief opportunity to summarize their opinions.").

191. See Roger J. Patterson, Dispute Resolution in a World of Alternatives, 37 CATH. U. L. REV. 591, 596-97 n.28 (1988) (claiming that, even if some live testimony is permitted, "it may be difficult to predict whether the outcome of a credibility contest in a summary proceeding will be representative of the results at trial'); $c f$. Rowland, supra note 6 (discussing possible disadvantages of summary jury presentations). A contrary argument can be made that shorter trials generally improve the quality of the jury's resolution. See William W. Schwarzer, Reforming Jury Trials, 1990 U. CHI. LEGAL F. 119. For example, in a long trial, certain desirable types of jurors may be unable to serve because of job conflicts. JoE S. CeCIL ET AL., JURY SERvice IN LENGTHY Crvil TrIALS 19-21 (1987).

192. The use of live testimony permits the jury to assess key witnesses' credibility, as opposed to judging the credibility of the attorneys. See supra note 22 . It also serves to reduce the risk of attorneys misrepresenting the evidence addueed during discovery. It may also serve to make the jury more aware of the human nature of the dispute. In addition, the binding SJT serves to reduce other concerns raised in connection with the classic SJT. For example, because the summary jury's decision is binding, the ethical criticisin leveled against the SJT for not informing jurors that their decision is advisory is avoided. See supra note 20 . Also, because parties must voluntarily agree to a binding SJT, the continuing debate over judicial authority to mandate its use, see supra notes 27-31 and accompanying text, is not an issue. 
It is unjustified to assume that all of the procedural niceties associated with a traditional jury trial are essential to a fair procedure; whether various evidentiary principles and trial techniques in fact ensure a "fair" trial is questionable. Litigants could rationally decide to forego many of these procedural amemities and accept a less-than-textbook-perfect trial if overall hitigation costs could be reduced and if the risk of aberrational jury decisions were controlled. Accordingly, the parties may choose to resurrect other trial conventions relatimg to such procedural variables as jury selection, cross-examination, evidentiary rules, and jury instructions. Even if some traditional trial accoutrements are reinstated, the possibility for significant reductions im trial length, and im overall cost savings, remaim. ${ }^{193}$ Many cases turn on a few critical issues, but adversarial instincts or the perceived need to bolster weak arguments may result in hitigants making repetitive presentations or raismg collateral issues during a traditional trial. ${ }^{194}$ The bimding SJT approach anticipates that the hitigants will agree to ccnter the trial on the key issues by either excluding jury consideration of collateral matters or estabhishnig firm limits on trial length to force hitigants' presentations to remain focused.

One of the primary procedural rights that parties would forego in a bimding SJT is the right to pursue post-trial remedies, such as the right to file an appeal. The binding agreement could replace these mechainsins with party-defined limits on the quantum of the jury award by utilizing a high/low agreement. Recent evidence indicates that post-trial processes constitute an important potential means of controlling errant jury awards, ${ }^{195}$ suggesting that it is a right that many hitigants might elect not to forego. Although evidence on post-trial adjustments remains sketchy, it appears that the various post-trial processes offer only linited and illdefined prospects for rehief, particularly for plaintiffs who have lost at trial. ${ }^{196}$ Accordingly, litigants imight readily prefer the certainty of their own negotiated solutions over the vagaries of existimg post-trial remedies.

193. In Table 1, an examination of nine binding SJTs-many of which included the use of live testimony and other traditional trial methods-indicates that substantial trial savings were achieved. See supra Table 1. In these cases, the estimated trial lengths of all the cases combined was 50 days. Assuming six hours per day of trial, the total trial length would have been about 300 hours. The binding SJTs actually consumed only about 100 hours, representing a $66 \%$ reduction in trial length. Id.

194. See Schwarzer, supra note 191, at 119-20.

195. For a discussion of the impact of post-trial adjustments on jury awards, see MichaEL G. Shanley \& Mark A. Peterson, Postrtrial Adjustments to Jury Awards (1987); Ivey E. Broder, Characteristics of Million Dollar Awards: Jury Verdicts and Final Disbursements, 11 Just. SYS. J. 349 (1986).

196. Shanley and Petersen found that $80 \%$ of jury awards were unaffected by the post-trial adjustment process; those awards that were nodified tended to be in cases with larger verdicts. See 
The litigants' agreement to waive their right to appeal does raise concerns that the parties may be tempted to violate applicable evidentiary norms, which may in egregious cases threaten the imtegrity of the binding SJT process. In a non-binding SJT, improper trial tactics are counterproductive; the opposing party lias the option of simply ignoring the tainted SJT result and proceeding to a conventional trial. In the binding context, lowever, this concern could be addressed by the parties who may authorize the presiding judge to order a retrial in cases in whicl1 a party engaged im grossly improper conduct. ${ }^{197}$

2. Predicting the Impact of Permitting Binding SJTs. What impact will recognizing and fostering the use of binding SJTs have on the litigation process? An imitial question is low often hitigants would agree to resolve their case using a summary process witl admitted imperfections. To be sure, the answer will depend upon developments not easily predicted. First, the incidence of use may be a function of judicial $\mathrm{m}$ volvement in permitting and indeed encouraging the procedure. Even thougli the parties must consent to the process, it would be appropriate for the court to play a facilitatimg role. Especially in jurisdictions that exercise active pre-trial management, courts could play a useful role im identifying cases im which the parties face a risky and expensive trial and are taking reasonable settlement positions. If the circumstances suggest the use of a binding SJT, the court could assist the litigants in estabhshing the high/low parameters and developing the fornat for the procedure. ${ }^{198}$ Use of the process will also depend to a great extent on the mterest of hitigants im utilizimg a lay jury. It may be, for example, that binding SJTs would be used more frequently in certain hitigation contexts

ShaNley \& PETERSEN, supra note 195, at 26-32. Cf. Galanter, supra note 187, at 224-27 (suggesting that judicial review of jury verdicts might be decreasing although becoining more focused on larger awards). In fact, virtually all substantial modifications represent reductions in jury awards, thus strongly suggesting that the process is of marginal use to plaintiffs. See SHANLEY \& PETERSEN, supra note 195, at 27-28 (Table 4.1) (reporting that plaintiff obtained rehief from post-trial adjustment process in only five percent of cases); Metzloff, supra note 126, at 60-61, 87-88 (questioning the rationality of the post-trial adjustment process). A binding SJT would alınost certainly be a more effective and efficient means of insuring plaintiffs some recovery in meritorious cases.

197. See Schneider, supra note 169 , at 4 (noting possibility of ordering a retrial for an unfair SJT); cf. Alfim, supra note 4, at 217 (noting attorney preference for soine safeguards against overly zealous presentations during summary jury proceedings). In addition, it could be argued that the court inaintains the inherent authority to review any trial conducted uuder its auspices to ensure that the proceeding was fundainentally fair. Although the scope of review would be linited, maintaining soine possibility for review-perhaps sinilar to that afforded to arbitration awards, see Federal Arbitration Act, 9 U.S.C. $\S 10$ (Supp. II 1990)-is advisable.

198. See Schneider, supra note 169, at 4 (describing judicial involvement in establishing high/ low agreeinents). 
such as personal injury disputes, ${ }^{199}$ where plaintiffs have a preference for lay juror involveinent, as opposed to business disputes, where the litigants might prefer experienced arbitrators.

It inay well be that the binding SJT option, even if inade available and encouraged by courts, would be used only infrequently. The procedure is sufficiently expensive such that settlement or other ADR options (such as arbitration) would in inany instances be preferred. But even if not used extensively, the availability of this ADR choice inay play a positive role. Plaintiff's attorneys, for example, might be inore inclined to initiate or be receptive to the use of ADR if a binding SJT were an option because it is inore akin to the familiar trial format. During the subsequent negotiations, the parties may agree on another ADR approach or even settle the dispute. ${ }^{200}$

Assuming that binding SJTs are regularly einployed, two potentially serious probleins may develop. First, by lowering the cost of trial and reducing the risk inherent in trial, the binding SJT inodel has the predictable effect of mcreasing the number of trials. This could contribute to court backlogs by requiring additional judicial involvement or commitinent of resources in cases that admittedly may have settled on their own

199. In North Carohina, there has been significant interest in the use of binding SJTs in the malpractice context. Over the past three years, five high-stakes malpractice cases have been resolved by binding SJTs, each involving awards to the plaintiffs of over $\$ 500,000$. See METZLOFF, supra note 73, at 19-28 (describing thrce of the cases). In comparison, the traditional trial process in North Carolina during the three years studied involved only two jury awards of this magnitude.

200. To date, there has been little discussion about how the provision of various ADR options enriches the settlement process. See generally Galanter, supra note 157, at 103 (discussing how certain procedural rules tend to "penetrate" the negotiation process apart from their formal use); $c f$. Robert H. Mnookin \& Lewis Kornllauser, Bargaining in the Shadow of the Law: The Case of Divorce, 88 YALE L.J. 950, 996 (1979) (noting tlat further study should be directed to "learning inore about how alternative procedural meclianisms miglit facilitate dispute resolution" in the context of child custody mediation).

Some evidence suggests that discussing ADR options assists in negotiations. For example, the author recently served as a consultant in exploring the use of ADR in a inajor obstetrical malpractice case. The parties had not discussed settlement for over a year, and were approximately $\$ 500,000$ apart on settlement. After preliminary discussions, the parties agreed in concept to use a binding SJT, which was the only ADR option that the plamtiff's attorney would consider. Following several meetings to determine the precise format, the parties reaclied a tentative agreement to use a two-day SJT focused solely on the obstetrician's alleged negligence (and excluding any evidence on the disputed issues of causation and damages), together vith a binding high/low agreement. As an order was being prepared for the court's approval, the parties reached a settlement. Both parties attributed the ADR discussions witl having served a key role in facilitating the settlement. The insurer in this dispute (who has been party to several binding SJTs) has reported that its consideration of ADR has helped settle several cases. See Medical Mutual Insurance Company of North Carolina, 1990 ANNUAL REPORT 6 (1990) ("We have found that simply proposing alternative dispute resolution often gets the discussion going again, which leads to settlements in cases that might otherwise go to court."). 
accord. The prospects of increasing the total number of trials being conducted under the court's auspices is both figuratively and literally unsettling.

One approach to minimize this potential drain on judicial resources would be to permit or even require the parties to retain private judges to preside over the summary trials. The North Carolina experience, for example, demonstrated considerable interest in that option. ${ }^{201}$ Litigants perceived several advantages to retaining a private judge, such as greater flexibility in scheduling, less potential interference from the courts in determining the SJT's format, and the inherent attractiveness of self-selecting the presiding judge. By the same token, however, the use of private judges strikes a discordant note with the repeated adınonition of SJT proponents that a public judge or magistrate must preside. ${ }^{202}$ In fact, however, this advice is more a reflection of the perceived need for formality than a comment on the unsuitability of private judges; experienced litigators or former judges should be able to set an appropriately formal tone. Although concerns have been raised concerning the use of private judges im other ADR contexts, ${ }^{203}$ their possible involvement in SJTs should not cause serious objection. Certainly, the task of presiding would appear to be no inore onerous than the responsibilities assigued to private attorneys who serve as arbitrators in court-ordered arbitration programs where they inust not only conduct the ADR hearings, but also decide the merits of the case. The use of private judges also serves to

201. Litigants in five of the nine binding SJTs in North Carolina employed private judges. METZLOFF, supra note 73, at 19-30 \& app. B.

202. See, e.g. , Breiner \& Simmer, supra note 15, at 310 ("To be most effective, the suinmary jury trial should be conducted by a judge or inagistrate. In order to have the same inpact on the litigants as the traditional trial, the summary jury trial must be adininistered by someone of authority in a courtroom."); Marcus, supra note 5, at 749 (noting that the "trappings" of the traditional trial process “are essential to [the SJT's] success; the sumnnary jury trial must be presided over by a judge or magistrate"). In fact, there are reports of non-judicial officers presiding. See Harges, supra note 50, at 810 n.103 (noting that one judge permitted his law clerks to preside over SJTs).

A separate issue is whether non-Article III judges are constitutionally permitted to preside in federal courts, a question that has received soine recent attention. See, e.g., Carrington, supra note 148, at 47-51 (noting that although it is increasingly tempting to delegate responsibility for presiding over jury trials to non-judges, an argument could be made that such delegation is constitutionally inpermissible). Currently, U.S. magistrates are permitted to preside with the consent of the parties. See 28 U.S.C. \$ 636(c) (1988). But see S. Elizabeth Gibson, Jury Trials in Bankruptcy: Obeying the Commands of Article III and the Seventh Amendment, 72 MiNN. L. REV. 967, 1044 n.358 (1988) (questioning whether the right to have an Article III judge preside over a jury trial can be waived).

203. See Note, The Califormia Rent-A-Judge Experiment: Constitutional and Policy Considerations of Pay-As-You Go Courts, 94 HARV. L. REV. 1592 (1981) (noting constitutional arguments and policy objections to the use of private judges, which permit wealthier litigants to obtain speedier resolutions of their disputes); Special Project, Self-Help: Extrajudicial Rights, Privileges and Remedies in Contemporary American Society, 37 VAND. L. REv. 845, 1019-29 (1984) (same). Assuining that the courts would be willing to supply a judge to preside, the concern with relative unfaimess would be mitigated. 
reduce any expenses incurred by the judicial system associated with the use of binding SJTs because hitigants would ordinarily be expected to pay the fees of the private judges. ${ }^{204}$

A second potential problein with the widespread use of binding SJTs concerns the relationship between the summary jury verdict results and the settlement of other cases. It has generally been assumed that conventional jury verdicts have a major impact on the settlement of non-trial disputes. ${ }^{205}$ Little attention has been given to how SJT verdicts might influence the settlement process, ${ }^{206}$ perhaps premised upon the assumption that SJT verdicts provided at best a faint signal because they were based upon incomplete evidence, or because they were often rendered in non-public settimgs. ${ }^{207}$

The potential impact of SJT verdicts becoines nore important, however, if the process were regularly used in a binding format. If, as suggested, a primary use of binding SJTs would be in high-stakes cases, the outcoines would be of considerable interest to attorneys and future litigants with similar cases. Moreover, several factors might result in more information on the summary verdict being generally available to interested observers. First, because the binding SJT is a binding trial conducted under the court's auspices, it is questionable whether it could be closed to the public, as have been soine classic SJTs. ${ }^{208}$ Second, because binding SJTs are shorter than trials, it is easier for reporters or interested

204. See Rex E. Lee, The American Courts as Public Goods: Who Should Pay the Costs of Litigation, 34 CATH. U. L. REV. 267, 268-71 (1985) (recommending imposition of appropriate user fees for trial); Posner, supra note 20, at 392-93 (suggesting imposition of user charges for court services in lieu of further development of SJTs); see also Thomas D. Rowe, Jr., Study on Paths to a "Better Way": Litigation, Alternatives, and Accommodation, 1989 Duke L.J. 824, 896-98 (discussing users' fees). Litigants could also be asked to pay the costs of summoning jurors to attend binding SJTs. In two of the five binding SJTs conducted in North Carolina using private judges, the litigants were required to reimburse the court for the cost of the jurors.

205. On the relationship between trial outcomes and the settlement process generally, see Galanter, supra note 187, at 227-232; Metzloff, supra note 126, at 80-93.

206. See Posner, supra note 20, at 388 (suggesting that if the use of non-binding SJTs increased, thereby reducing the number of trial decisions, it would tend to make it more difficult for litigants to predict trial outcomes, resulting in greater uncertainty that would destabilize the settlement process).

207. See, e.g., Cincinnati Gas \& Elec. Co. v. General Elec. Co., 854 F.2d 900 (6th Cir. 1988) (permitting SJT hearing to be closed to the public), cert. denied, 489 U.S. 1033 (1989).

208. The justification used in Cincinnati Gas-that the procedure was simply part of an elabo. rate settlement process-will be unavailing in the binding context. Litigants may prefer that the summary trials be closed, however, for other reasons. The increased potential for privacy is a major perceived benefit of ADR procedures. For discussion of the issues relating to access to SJTs, see Andrew G. Sykes, Cincinnati Gas \& Electric Co. v. General Electric Co.: Extinguishing the Light on Summary Jury Trials, 49 OHo ST. L.J. 1453 (1989) (suggesting a qualified right of access to SJTs). For an excellent discussion of the policy issues relating to conducting private SJTs, see Carrie Menkel-Meadow, Pursuing Settlement in an Adversary Culture: A Tale of Innovation Co-opted or "The Law of ADR," 19 FlA. St. L. REV. 1, 25-30 (1991). 
observers to attend the proceedings. Third, because summary trials are still novel, they may receive more publicity than traditional trials. ${ }^{209}$

The shadows cast by SJT verdicts would not pose a special concern if the quality of decision were as high as traditional trials. Because of the abbreviated nature of the presentation, however, binding SJT results may be inore prone to erratic results than are regular jury trials. The combination of less predictable results and higher-stakes cases may lead to increased instability in the settlement process. In addition, observers who are not privy to the parties' high/low agreements (which are usually confidential), inay interpret the summary jury results incorrectly by failing to take into account the hitigants' actual use of the summary verdicts. ${ }^{210}$ One possible solution would be to encourage hitigants to define more carefully the issues submitted to the suinmary jury so that the results were less susceptible to misinterpretation. For example, if the primary issue to be resolved by the summary jury is hability, then the question of dainages should not even be submitted to the summary jury so as to avoid any possibly negative impact of an unusually large or sinall award.

\section{Conclusion}

Courts are faced with difficult choices as to what ADR options to promote and institutionalize. In considering the SJT-a leading ADR candidate based upon its alleged propensity to proinote settlements in intractable cases-one is confronted with sharply conflicting accounts of its performance and promise. The classic SJT is schizophrenic. On one

209. Several of the binding SJTs conducted under the North Carolina SJT program received front page coverage in a statewide publication for lawyers. See Michael Dayton, Summary Jury Trial Returns First Breast Cancer Verdict, N.C. LAw. WKLY., Mar. 5, 1990, at 1; Jay Reeves, MiniTrial Reaps \$8 Million Award, N.C. LAw. WKLY., June 12, 1989, at 1.

210. The possibly negative impact associated with widely known SJT results can be illustrated by Phillips v. Huffinan, No. 89-CVS-2072 (N.C. Super. Ct. May 30, 1989) (Catawba County) (described in METZLOFF, supra note 73, at 19-22). In Phillips, the primary issue subunitted to the summary jury was whether an obstetrician had negligently handled a inother's pregnancy, which had allegedly resulted in severe neurological injuries to the plaintiff child. The defendant submitted no evidence on the issue of damages because if hability were found, the quantum of damages would clearly have exceeded the parties' high/low agreement; the plaintiff would thus receive the maximum award. Nonetheless, the issue of damages was submitted to the jury, who, based upon incomplete information, rendered a verdict for $\$ 8$ imillion (which, had it occurred in a regnlar jury trial, would have been the largest inalpractice verdict ever rendered in North Carolina).

Informal discussions with insurers indicated that the high SJT verdict had made settlennent of other obstetrical malpractice cases more difficult because it had established a new target figure for plaintiffs' attorneys. Certainly with respeet to the SJT process, the verdict raised grave doubts in the minds of defense counsel as to the faimess of the process (even though the issue of damages had not actually been contested at the trial). See supra notes 119-24 and accoinpanying text. In retrospect, it might have been preferable-and indeed fairer to the suminary jury-simply to submit the issue of liability. 
hand, it accepts the existing dynamics for pre-trial discovery and settleinent, despite growing evidence that those processes may be inefficient, expensive, and potentially unfair. On the other hand, with respect to the trial process itself, the SJT rejects virtually all existing safeguards, and replaces them with an emaciated version of a traditional trial. This sharp division in approach provides fertile grounds for criticisin. The evidence presented here is that the classic SJT is an unattractive option for many courts and in many litigation contexts.

The intensity of recent criticisins of the SJT is unwarranted. The process remains in an experimental phase; it has in its brief history evolved from a sharply regimented procedure used in a narrow band of cases to a more free-wheeling and flexible mechanism. Its stated justifications, however, remain closely tied to its earhest inanifestations. Too much attention has been given to debating the merits of an admittedly experimental process, and too hittle to reexamining and refining its role in the continumg evolution of ADR procedures. The key issue may not be determining whether thc SJT has been proven "effective" as defined by some artificial measure, but to contimue to debate what role the process may play in contributing to improvements in the settlement/litigation dynamic.

Looking past the classic SJT's narrowly defined purpose of reducing trial dockets, there emerges a different vision of what the SJT might accomphish. To date, the ADR movement-especially those aspects that relate to court-annexed alternatives-has focused on ways to facilitate early settlements. A different vantage point recognizes that the settlement process itself may be unfair and inefficient. If true, developing ADR methods designed for cases that are currently settling is a legitimate and important task; that this endeavor might require creating methods that postpone settlement or that seek to change the patterns of settlement incentives should be acknowledged and viewed as a worthy challenge. In that hight, the SJT-reconfigured as a binding process targeted at high-stakes disputes-can fulfill a worthy niche. 